\title{
Evidence of Contemporary and Ancient Excess Fluid Pressure in the New Madrid Seismic Zone of the Reelfoot Rift, Central United States
}

U.S. GEOLOGICAL SURVEY PROFESSIONAL PAPER 1538-N

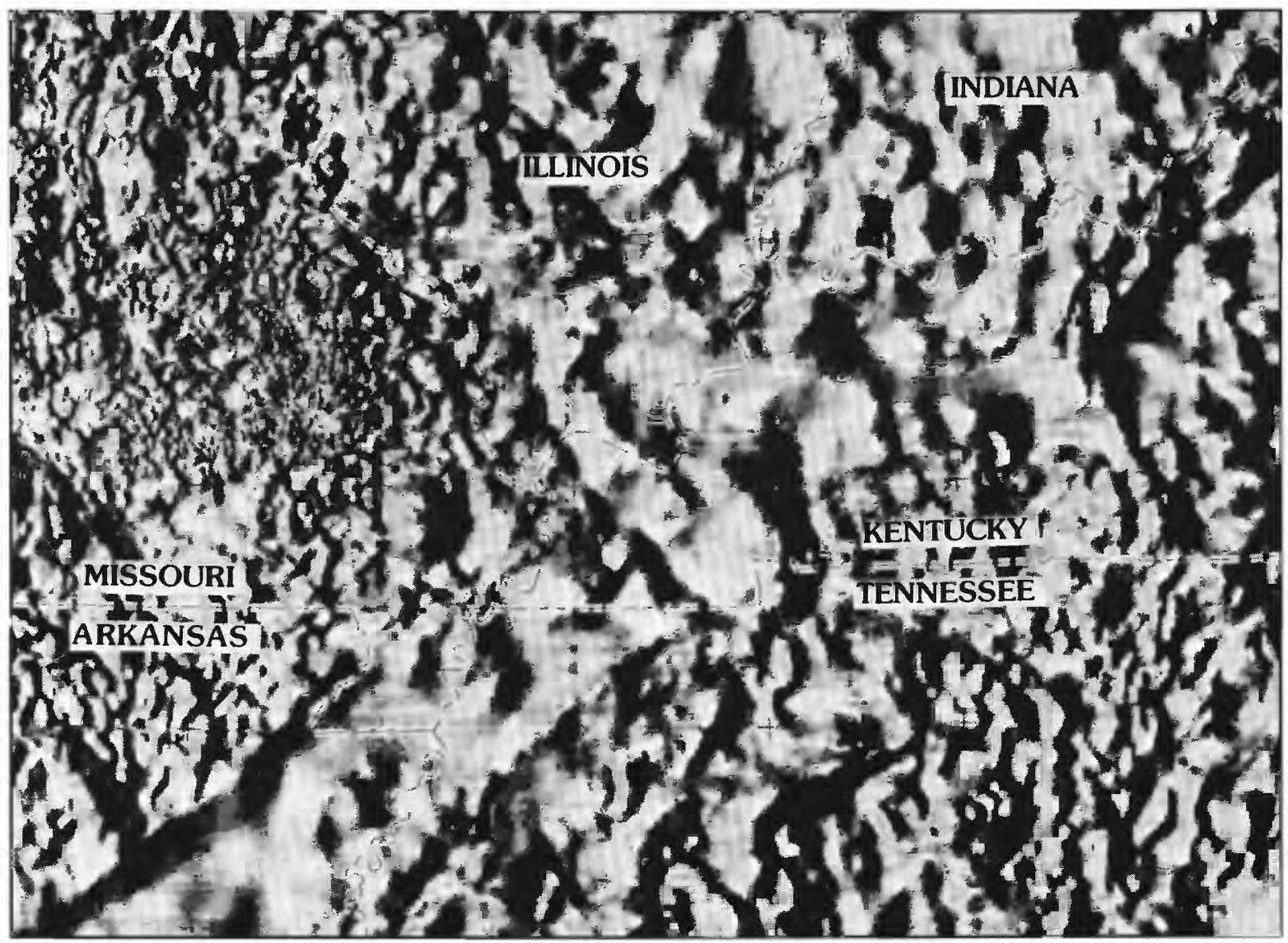


Cover. Gray, shaded-relief map of magnetic anomaly data. Map area includes parts of Missouri, Illinois, Indiana, Kentucky, Tennessee, and Arkansas. Illumination is from the west. Figure is from Geophysical setting of the Reelfoot rift and relations between rift structures and the New Madrid seismic zone, by Thomas G. Hildenbrand and John D. Hendricks (chapter $\mathrm{E}$ in this series). 


\section{Evidence of Contemporary and Ancient Excess Fluid Pressure in the New Madrid Seismic Zone of the Reelfoot Rift, Central United States}

By F.A. McKeown and S.F. Diehl

INVESTIGATIONS OF THE NEW MADRID SEISMIC ZONE Edited by Kaye M. Shedlock and Arch C. Johnston

U.S. GEOLOGICAL SURVEY PROFESSIONAL PAPER 1538-N

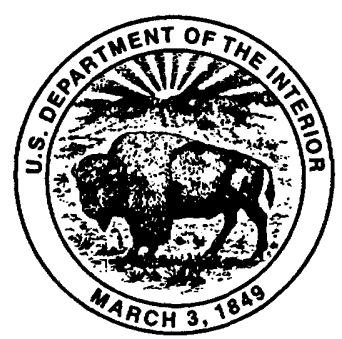




\title{
U.S. DEPARTMENT OF THE INTERIOR BRUCE BABBITT, Secretary
}

\author{
U.S. GEOLOGICAL SURVEY \\ Gordon P. Eaton, Director
}

For sale by U.S. Geological Survey, Map Distribution Box 25286, MS 306, Federal Center

Denver, CO 80225

\begin{abstract}
Any use of trade, product, or firm names in this publication is for descriptive purposes only and
\end{abstract} does not imply endorsement by the U.S. Government

\section{Library of Congress Cataloging-in-Publication Data}

McKeown, F.A. (Francis Alexander), 1920-

Evidence of contemporary and ancient excess fluid pressure in the New Madrid seismic zone of the Reelfoot rift, Central United States

/ by F. A. McKeown and S.F. Diehl.

p. cm. - (Investigations of the New Madrid seismic zone; $\mathrm{N}$ )

(U.S. Geology Survey professional paper; 1538-N)

Includes bibliographical references.

Supt. of Docs. no.: I 19.16:1538-N

1. Seismology-Missouri-New Madrid Region. 2. Geology, StructuralMissouri - New Madrid Region. 3. Aquifers-Missouri-New Madrid Region. I. Diehl, S.F. II. Title. III. Series. IV. Series: U.S. Geological Survey professional paper; 1538-N.

QE535.2.U6I59 1994 vol. N

$551.2^{\prime} 2^{\prime} 09788985 \mathrm{~s}-\mathrm{dc} 20$

[551.2'2'09788985] 


\section{CONTENTS}

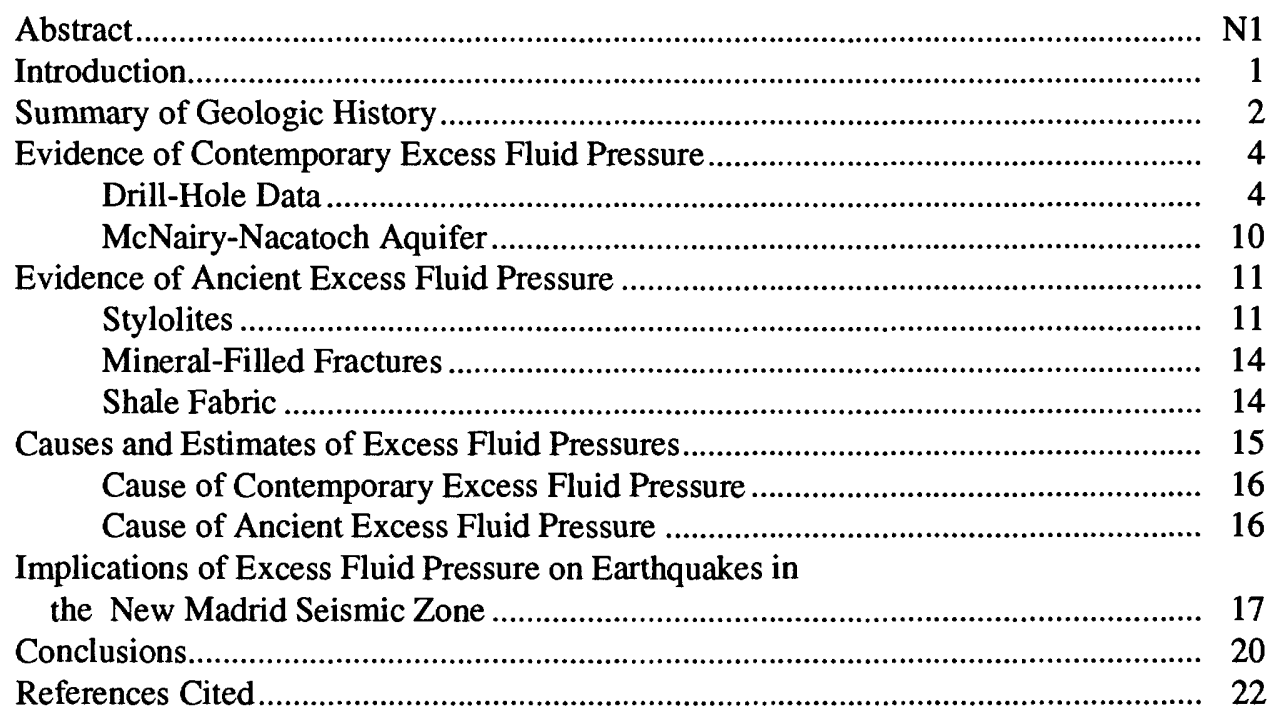

\section{FIGURES}

1. Index map of the New Madrid region showing epicenters, plutons, rift boundaries, selected drill holes, Blytheville-Pascola arch complex, and seismic reflection profile lines

2. Schematic diagrams showing temporal and structural evolution of the Reelfoot rift, the Blytheville-Pascola arch complex, and the Mississippi Embayment syncline

3. Coherency-filtered, unmigrated seismic reflection record section of line P1 and line drawing extending from southeast boundary of Reelfoot rift northwestward across southwest end of the Blytheville-Pascola arch complex.

4. Coherency-filtered, unmigrated north-south seismic reflection record section of line P2 and line drawing processed to intersect Blytheville-Pascola arch complex at about $90^{\circ}$

5. Columnar section of hydrogeologic units in the upper Mississippi Embayment.

6. Map showing locations of wells that penetrate Paleozoic rocks

7. Map showing locations of wells that penetrate the Upper Cretaceous aquifer

8. Map showing zones of anomalously warm water and contours of $P$-wave velocities in upper $14 \mathrm{~km}$ of the crust in relation to the Reelfoot rift and the Blytheville-Pascola arch complex

9. Thin section photomicrographs of stylolites in the Wilson drill hole and deformed stylolites in the Garrigan drill hole

10. Thin section photomicrograph showing network of vertical and horizontal fractures filled with epigenetic carbonate minerals

1. Scanning electron photomicrographs of well-laminated and randomly oriented clay platelets in shale

12. Generalized map derived from figures 1,6 , and 7 showing relationship of the Blytheville-Pascola arch complex and excess-fluid-pressure zone to seismicity

\section{TABLE}

1. Estimates of excess pressures at bottom of drill pipes 
METRIC CONVERSION FACTORS

\begin{tabular}{lll}
\hline \multicolumn{1}{c}{ Multiply inch-pound unit } & By & To obtain metric (SI) unit \\
\hline & & \\
inches & 0.02540 & meters (m) \\
feet (ft) & 0.3048 & meters (m) \\
miles (mi) & 1.609 & kilometers $(\mathrm{km})$ \\
gallons per minute (gal/min) & $6.309 \times 10^{-2}$ & liters per second (L/s) \\
pound-force per inch ${ }^{2}(\mathrm{psi})$ & $6.895 \times 10^{-3}$ & megapascals (MPa) \\
& & \\
\hline
\end{tabular}

Temperature in degrees Fahrenheit $\left({ }^{\circ} \mathrm{F}\right)$ may be converted to degrees Celsius as follows: ${ }^{\circ} \mathrm{C}=5 / 9\left({ }^{\circ} \mathrm{F}-32\right)$

Pressure in bars may be converted to megapascals by multiplying by 0.10 


\title{
EVIDENCE OF CONTEMPORARY AND ANCIENT EXCESS FLUID PRESSURE IN THE NEW MADRID SEISMIC ZONE OF THE REELFOOT RIFT, CENTRAL UNITED STATES
}

\author{
By F.A. McKeown and S.F. Diehl
}

\begin{abstract}
Geophysical and seismological data indicate that most earthquakes in the New Madrid seismic zone are associated with a structural high composed of intensely disrupted rocks along the axis of the Reelfoot rift; the high is inferred to be structurally weak and, therefore, is more likely to fail than adjacent rocks. The structural high is within a part of the upper Mississippi Embayment where hydrologic data show that excess fluid pressure is pervasive in aquifers below the Paleocene Midway Group confining unit where the group is more than $200 \mathrm{ft}$ thick. In addition, low seismic velocities and relatively low resistivities to depths of more than $5 \mathrm{~km}$ have been interpreted to be caused by excess fluid pressure. The principal evidence of excess fluid pressure is artesian flow from aquifers in Paleozoic rocks at depths greater than $1 \mathrm{~km}$ and from wells in the Upper Cretaceous McNairy-Nacatoch aquifer. Hydraulic continuity of the Paleozoic and Cretaceous aquifers and circulation of water from great depths are indicated by chemical and thermal data of water samples. Vertical continuity through heterogeneously distributed fracture zones in the Blytheville-Pascola arch complex is interpreted from seismic reflection profiles. Because most seismicity in the New Madrid zone is spatially coincident with areas where excess fluid pressure is present in the disrupted arch complex, a causal relationship is suggested. Special conditions for gravity flow and confining layers that may explain contemporary and ancient excess fluid pressures were present during the late Paleozoic and probably early Mesozoic as well as since the Eocene. Excess ancient fluid pressure is clearly evident in petrographic studies of samples of lower Paleozoic rocks from drill holes. Dilation and mineral filling of stylolites and fractures and the fabric of shales are the principal evidence of ancient excess fluid pressure. The paragenetic sequence of minerals determined from these studies and a wealth of data on the source of ore fluids for lead-zinc deposits in the Ozarks show that several episodes of excess fluid pressure occurred during a period of
\end{abstract}

several million years. The special conditions for contemporary excess fluid pressure probably existed since the Eocene; however, the style of faulting differed from that of today. The northeasterly strike of normal faults in Tertiary and Quaternary rocks indicate that the direction of maximum principal stress was rotated about $35^{\circ}$ counterclockwise from the direction of the present stress field. Seismicity trends and focal mechanisms, therefore, would have been unlike those of today in the embayment. The lack of northeast-striking normal faults since about the Pleistocene suggests that the stress field changed to its present direction and that current seismicity associated with strike-slip movement on northeasterly striking faults may have started at about that time. Current seismicity in the Blytheville-Pascola arch complex, therefore, may be a long-lived phenomenon and not an aftershock sequence of the 1811-12 earthquakes. Estimates of the excess fluid pressures in the New Madrid seismic zone are less than the pressure changes known to trigger earthquakes. Because of much uncertainty about the state of stress at hypocentral depths and evidence of changes in seismicity related to very small changes in fluid pressure, consideration is warranted of a causal relationship of the excess fluid pressure to seismicity in the New Madrid region. If the relationship is causal, many ramifications should be considered. These include establishing a physical basis for delimiting seismic zones, estimating when background seismicity started, and possibly estimating recurrence rates of earthquakes in a region as a function of source-zone size and the time required to pressurize a source zone by fluid flow.

\section{INTRODUCTION}

A difficult problem in evaluating earthquake hazards is to establish a physical basis for delimiting earthquake source zones. Although the location, stress directions, and mechanisms of earthquakes can be obtained from seismicity, information about the physical properties of rocks in an 
earthquake source zone must be obtained from geologic and geophysical data. The term physical properties as used in this report refers to the gross or volume-averaged properties of rock, which may be quite unlike physical properties measured on centimeter-sized samples. If the physical properties known to contribute to failure of rocks in active seismic zones are known and the regional state of stress is fairly uniform, as indicated by the stress map of Zoback and Zoback (1981), the probable extent of the zone can be mapped independently of the current seismicity. Furthermore, identification, or inference, of similar properties in other areas may be used in the preparation of earthquake hazard maps-this information from other areas may also enhance the credibility of the maps. Resolving this problem requires: (1) identification of the physical properties of a seismically active source zone, (2) identification of the geologic factors that produced those properties, and (3) an explanation of why such properties cause or are conducive to the generation of earthquakes.

Geophysical and seismological data show that most earthquakes in the New Madrid seismic zone occur within a structural high in lower Paleozoic rocks along an approximately 10-km-wide axial zone of the Reelfoot rift (Crone and others, 1985; Hamilton and McKeown, 1988; McKeown and others, 1990). The Blytheville (axial) structural high merges with the Pascola arch, which is about $40 \mathrm{~km}$ wide. Because the Blytheville and Pascola are coextensive and apparently cogenetic, we refer to them herein as the Blytheville-Pascola arch complex (fig. 1). Seismic reflection profiles indicate that the rocks in the high are intensely disrupted, which implies that the zone is structurally weak and which explains, at least in part, the occurrence of earthquakes (Crone and others, 1985; Hamilton and McKeown, 1988; McKeown and others, 1990). In addition, low seismic velocities and relatively low electrical resistivities of these rocks suggest that they contain pore fluids that have excessively high fluid pressure compared to adjacent rocks (Al-Shukri and Mitchell, 1988; Hamilton and Mooney, 1990; Stanley and Rodriquez, 1992). Sibson (1990) has suggested that, in the northern part of the New Madrid seismic zone, reverse faults unfavorably oriented to the current stress field are seismically active because of fluid-overpressured cracks.

We use "excess fluid pressure" to describe any pressure that is greater than the hydrostatic pressure and the term "pore pressure" primarily to refer to fluid pressure in fractures or faults and interstitial pore space. Undoubtedly, some of the rock is porous and has fluid pressure in the pores, but the extent and abundance of porous rock is not known. Lithostatic pressure is analogous to overburden pressure and is defined as equal to the pressure caused by the weight of a column of overlying rock.

The principal objectives of this paper are: (1) to present direct and circumstantial evidence of excess fluid pressure in the New Madrid seismic zone, (2) to present geologic reasons for contemporary excess fluid pressure, (3) to present evidence that excess fluid pressure existed in late Paleozoic and probably early Mesozoic time, and (4) to discuss the implications of excess fluid pressure to seismicity in the New Madrid seismic zone.

Perhaps the most significant observation reported in this paper is that most seismicity in the New Madrid seismic zone occurs primarily where excess fluid pressure is inferred in the arch complex. Seismicity decreases abruptly to the north of the arch complex where fluid pressure is not excessive (but where structural disruption very likely exists) because this area coincides with the intersection of major northeast- and northwest-striking fault zones (Hildenbrand and others, 1992). Seismicity also decreases abruptly to the south where the arch complex terminates but where fluid pressures are inferred to be excessively high. We suggest that earthquake activity in the New Madrid seismic zone requires both structurally disrupted rocks and excess fluid pressure.

The primary emphasis of most earthquake studies is to identify the seismic source zones. The ultimate reason for this paper, however, is an attempt to explain why certain geologic structures in the New Madrid seismic zone are seismically active whereas others are not, despite an abundance of major faults in the region that are suitably oriented for slip in the contemporary stress field.

Acknowledgments.-We wish to thank several U.S. Geological Survey colleagues for helpful criticisms and discussion. John Bredehoeft, Anthony Crone, Evelyn Roeloff, and Martin Goldhaber provided thoughtful and helpful reviews. William Ellis and Henri Swolfs kept us from making some very erroneous statements about pressure and stress. Harold Olsen explained how to calculate frictional loss of pressure in pipes. Rus Wheeler raised some pertinent questions on our early draft, and Walter Mooney encouraged us to write the paper. Discussions with John Van Brahana were invaluable, and he provided much of the hydrologic data that we discuss in the paper.

\section{SUMMARY OF GEOLOGIC HISTORY}

Major advances in knowledge of the subsurface structure in the embayment have resulted from studies of a variety of geophysical data and a few deep drill holes (Kane and others, 1981; Mooney and others, 1983; Howe and Thompson, 1984; Hildenbrand, 1985; McKeown and others, 1990; Diehl and others, 1992; Swolfs, 1992). These studies have emphasized the tectonic history of the upper Mississippi Embayment region. However, the data on the distribution and cause of excess fluid pressures require a broader perspective of the geologic history than just tectonics. Important aspects of the geologic history are the location of upland areas at various periods of geologic time and the ages, lithology, and erosion of sedimentary rocks. Of particular importance is the geologic record and history of fluid flow in the region, a topic 


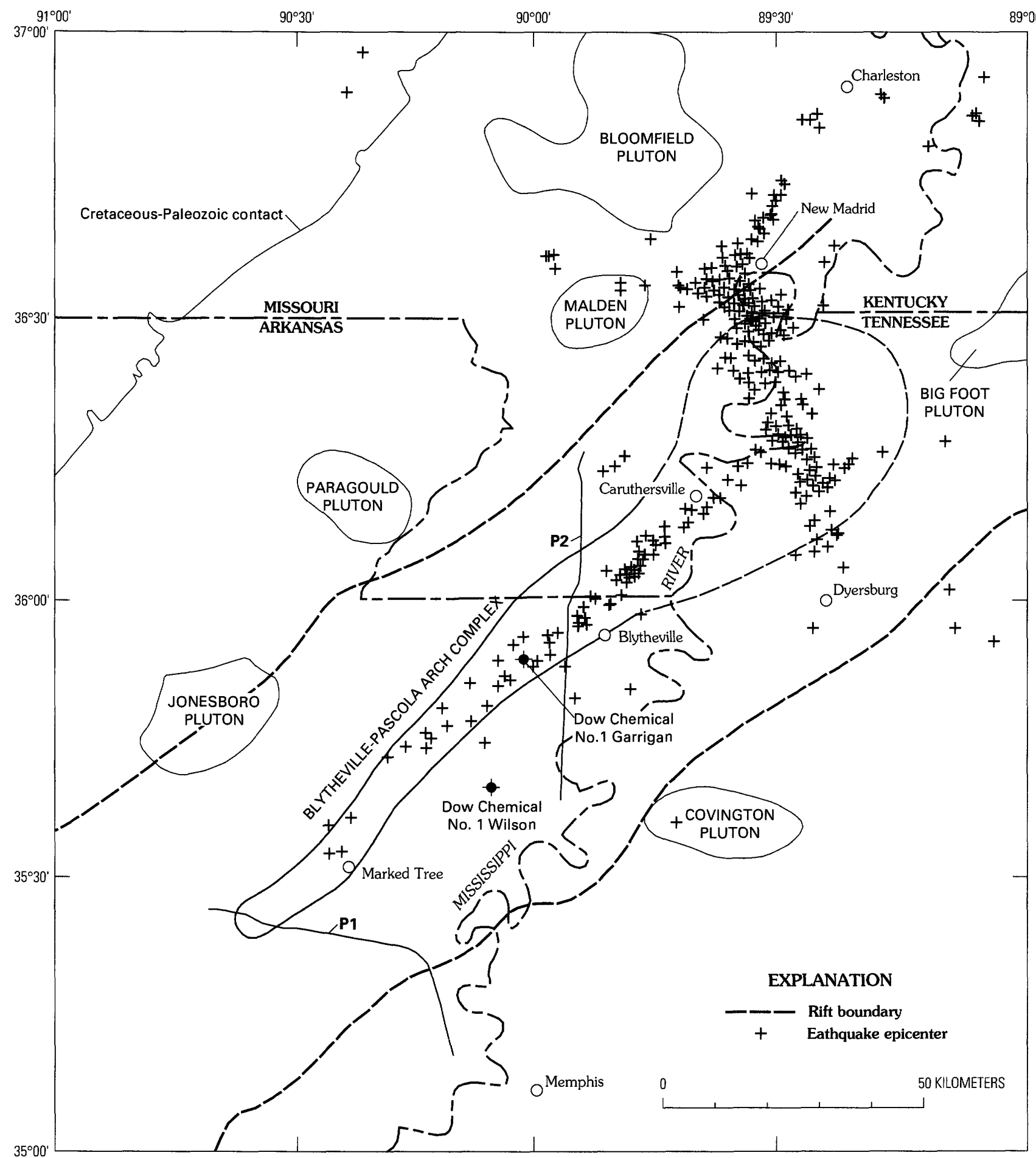

Figure 1. Index map of the New Madrid region showing earthquake epicenters (Andrews and others, 1985), plutons, rift boundaries, Blytheville-Pascola arch complex, and selected drill holes. Solid line boundary of arch complex is from seismic reflection profiles and drill-hole data; long dashed line boundary is from drill-hole data. P1 and P2 show locations of east-west and north-south seismic reflection profiles, respectively. 
that has been studied extensively for many years in efforts to explain the distribution and origin of Mississippi Valley-type lead-zinc ore bodies (Leach and Rowan, 1986). In addition, recent hydrologic studies of flow directions and the chemistry of ground water in the upper Mississippi Embayment region bear directly on postulating the existence and distribution of excess fluid pressure in the shallow and deep subsurface (Brahana and Mesko, 1988).

The Reelfoot rift is inferred to have formed in Late Proterozoic or Early Cambrian time (Ervin and McGinnis, 1975). No definitive evidence of the rift's Late Proterozoic age is known, but rifting occurred during the Cambrian as indicated by the thick section of Cambrian rocks along the middle of the rift (Howe and Thompson, 1984; McKeown and others, 1990). During the Late Cambrian, valleys were incised into Precambrian igneous rocks in the Ozark dome (Schwalb, 1982) and were filled with sandstone. The Ozark and Nashville domes were structural and topographic highs for part of the time after the Early Ordovician (Wanless, 1975; Buschbach and Atherton, 1979), but several major transgressions of shallow seas, which deposited carbonate rocks over broad areas, were interspersed with minor uplifts in the Ordovician, Silurian, Devonian, and Mississippian. Sandstone and siltstone were commonly deposited adjacent to the uplifts. By Pennsylvanian time, the Ozark and Nashville domes were low landmasses and were covered by shallow lakes, swamps, lagoons, and shallow seas. Later in the Pennsylvanian, uplift exposed mainly carbonate rocks in which a complex of sinkholes and caves formed. Some of the caves and sinks are filled with Pennsylvanian rocks more than $90 \mathrm{~m}$ thick (Wanless, 1975).

Because of the close association of earthquakes and the possibility of structural traps for hydrocarbons, the origin and structural characteristics of the Blytheville-Pascola arch complex have been of considerable importance since the complex was first discovered (Howe and Thompson, 1984; Crone and others, 1985). McKeown and others (1990) proposed that the Blytheville-Pascola arch complex formed by diapirism starting during the late Paleozoic. Diapiric movement in the thickest section of clastic rocks (composed largely of shale, siltstone, and fine-grained sandstone) along the axial part of the Reelfoot rift may have been triggered by unloading when a thick section of Mississippian and Pennsylvanian rock was eroded, or it may have been triggered by overpressure conditions in the clastic rocks. As we discuss later in this report, excess fluid pressure probably existed in the Cambrian and Ordovician rocks at this time and could have been a major factor in making the fine-grained clastic rocks that fill the axial part of the rift more ductile and less dense than the laterally contiguous rocks. After formation of the Blytheville-Pascola arch complex, a long period of uplift and erosion began, which lasted until the Late Cretaceous, when downwarping began to form the Mississippi Embayment syncline (Stearns and Marcher, 1962). Cretaceous, Paleocene, and lower Eocene rocks, amounting to about 1 $\mathrm{km}$ in thickness, were deposited in the upper part of the embayment during a sequence of five marine transgressions and regressions (Stearns, 1957). The maximum transgression, during the Paleocene, deposited the Porters Creek Clay. A generalized evolution of the Reelfoot rift and the Blytheville-Pascola arch complex, as described above, is schematically shown in figure 2 . The principal evidence for the stages of rifting has been described by McKeown and others (1990) and is shown in the seismic reflection profile of figure 3. Identification of the principal reflectors, which is critical to the structural events interpreted in the profile, was based on a synthetic seismic reflection profile made from sonic, density, and lithologic logs of the Dow Chemical No. 1 Wilson hole (fig. 1) (E. Luzietti, written commun., 1989). The arching of strata by the Blytheville-Pascola arch complex, shown in figures 3 and 4 , is well documented in numerous other seismic reflection profiles.

It is particularly important to note in figure 2 that stratigraphic units known, or inferred to contain, many thick confining layers, which could act as caps to underlying aquifers, were present during only two periods: one was when Mississippian and Pennsylvanian rocks with many confining layers covered much of the region (fig. 2) (Wanless, 1975); the second was when Tertiary clays were deposited in the embayment.

\section{EVIDENCE OF CONTEMPORARY EXCESS FLUID PRESSURE}

Well-documented data on water levels and water chemistry provide abundant evidence that the current fluid pressure is excessively high in several aquifers in the upper Mississippi Embayment. Interpretations of hydrologic data are commonly made by combining stratigraphic units that are hydrologically distinct into hydrostratigraphic or hydrogeologic units (Maxey, 1964; Seaber, 1988). The hydrogeologic units used in this study (fig. 5) are from Brahana (written commun., 1992) and Imes and Smith (1990).

\section{DRILL-HOLE DATA}

The most spectacular evidence in recent years of contemporary excess fluid pressure in Paleozoic rocks was the artesian flow of water from the New Madrid test well (fig. 6) (Crone and Russ, 1979; Crone, 1981). Dolomite was first penetrated in the well at a depth of $2,023 \mathrm{ft}$. The rocks in the well above the Paleozoic and Upper Cretaceous are predominantly fine grained, of which the most impermeable are the Paleocene Porters Creek Clay (314 $\mathrm{ft}$ ) and the Eocene Cook Mountain Formation (178 ft). The very high clay content was determined from core and is indicated by the low resistivity on geophysical logs of the New Madrid test well (Crone and Russ, 1979, fig. 3 
Middle(?) and Late Cambrian

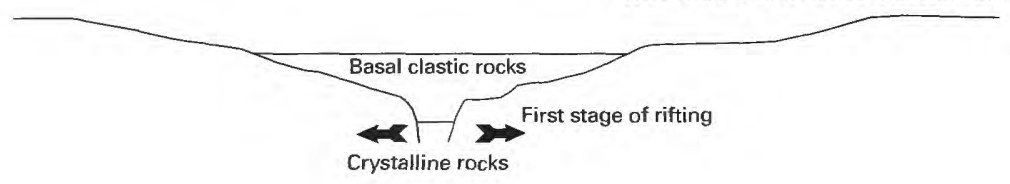

Late Cambrian

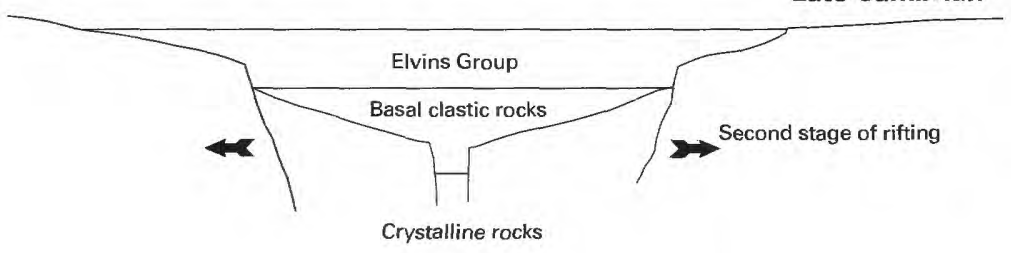

Late Cambrian-Ordovician

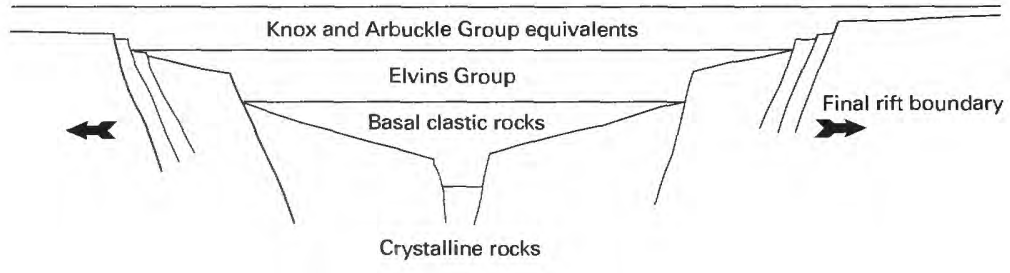

Post Ordovician-pre-Upper Cretaceous

Post Ordovician-pre-Late Cretaceous

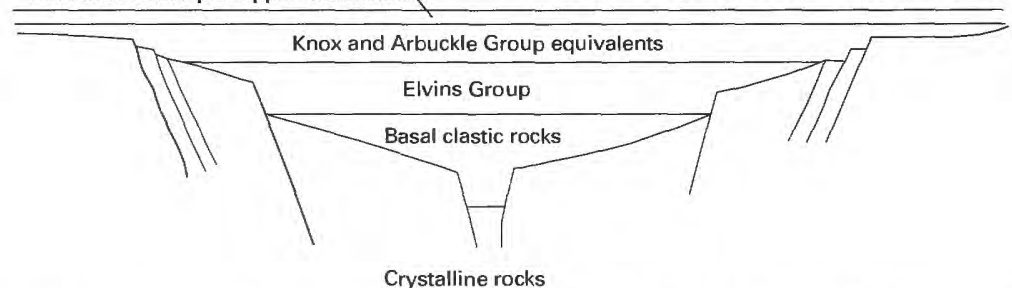

Crystalline rocks
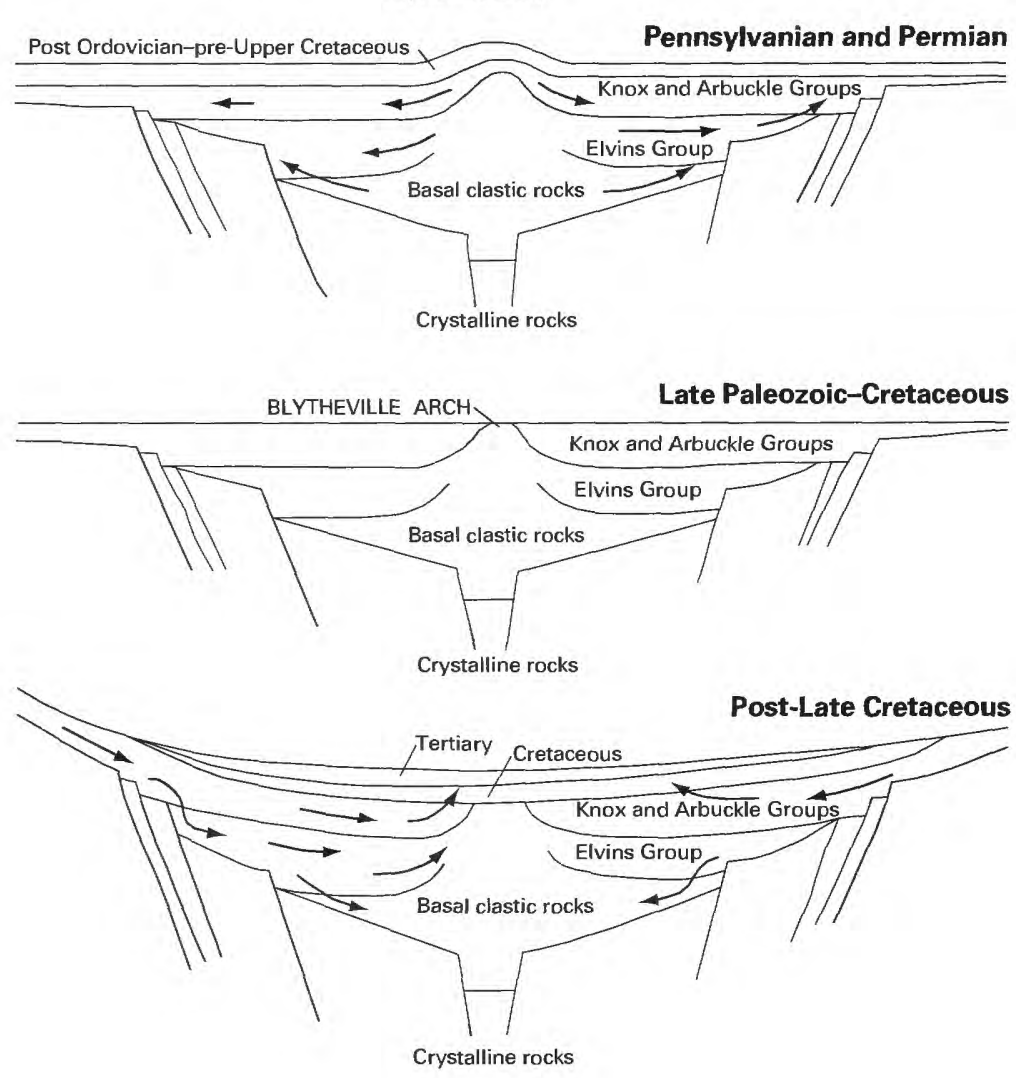

Figure 2. Schematic diagrams showing temporal and structural evolution of the Reelfoot rift, the Blytheville-Pascola arch complex, and the Mississippi Embayment syncline. Bold arrows with tails indicate rift movement. Arrows without tails indicate flow directions. 


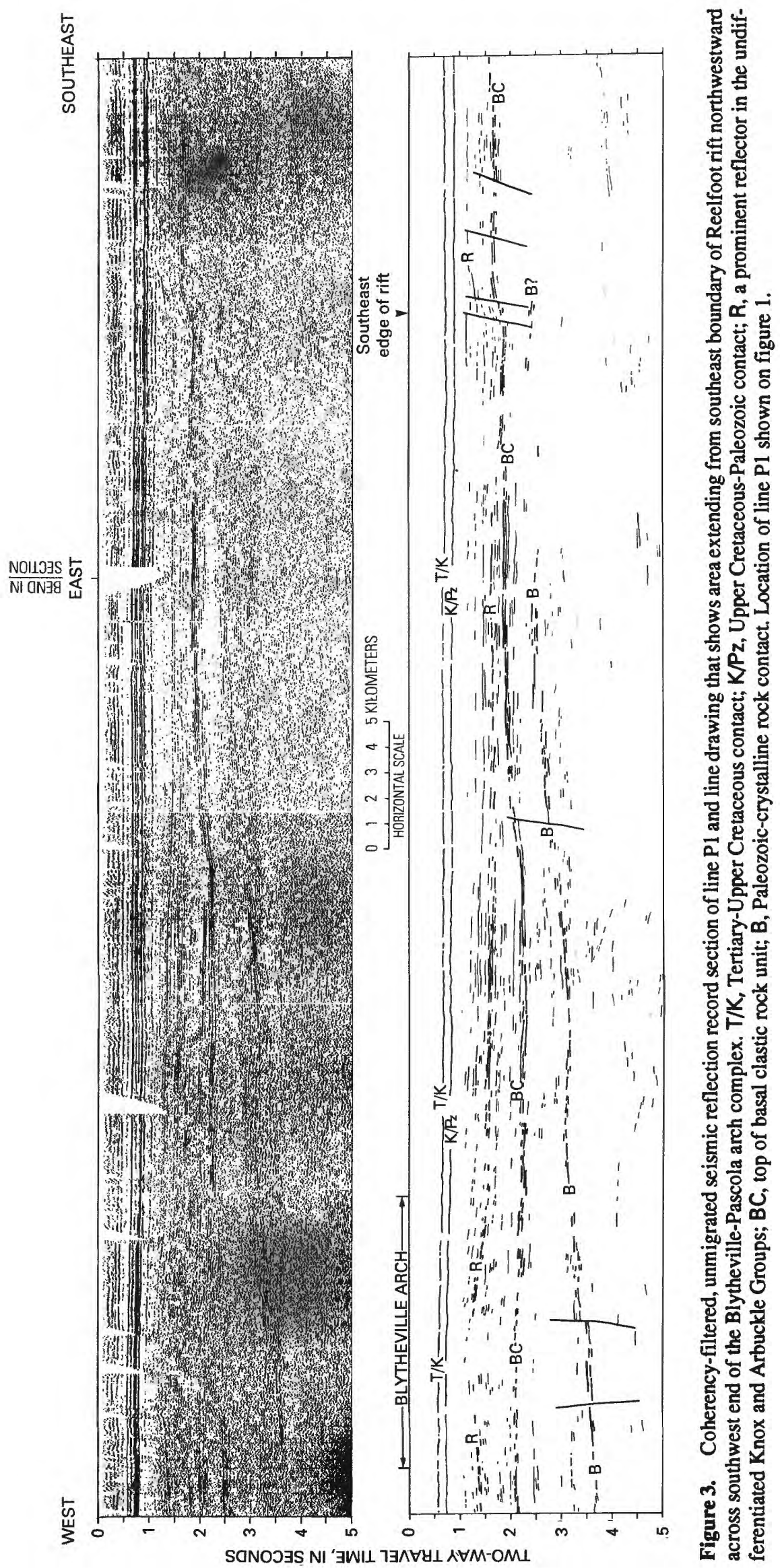




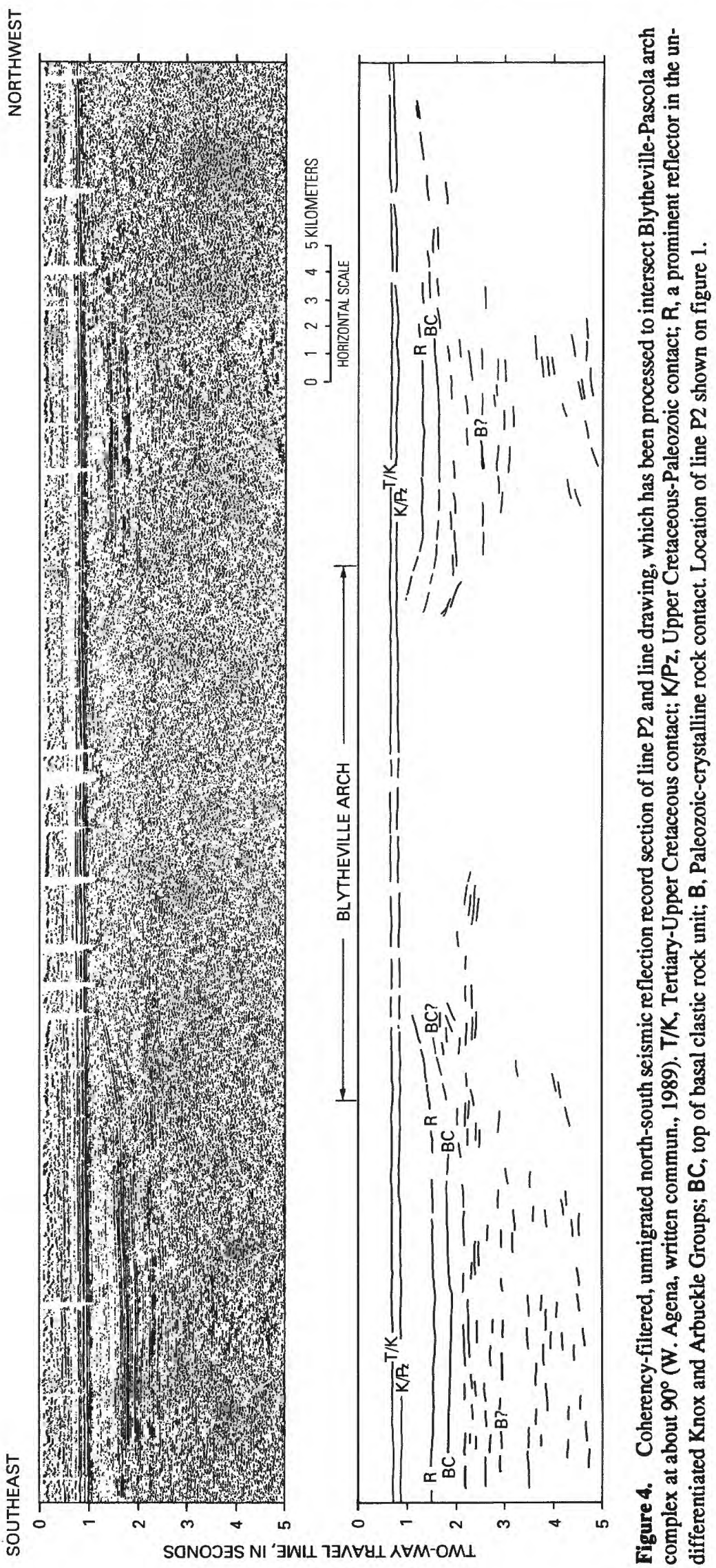




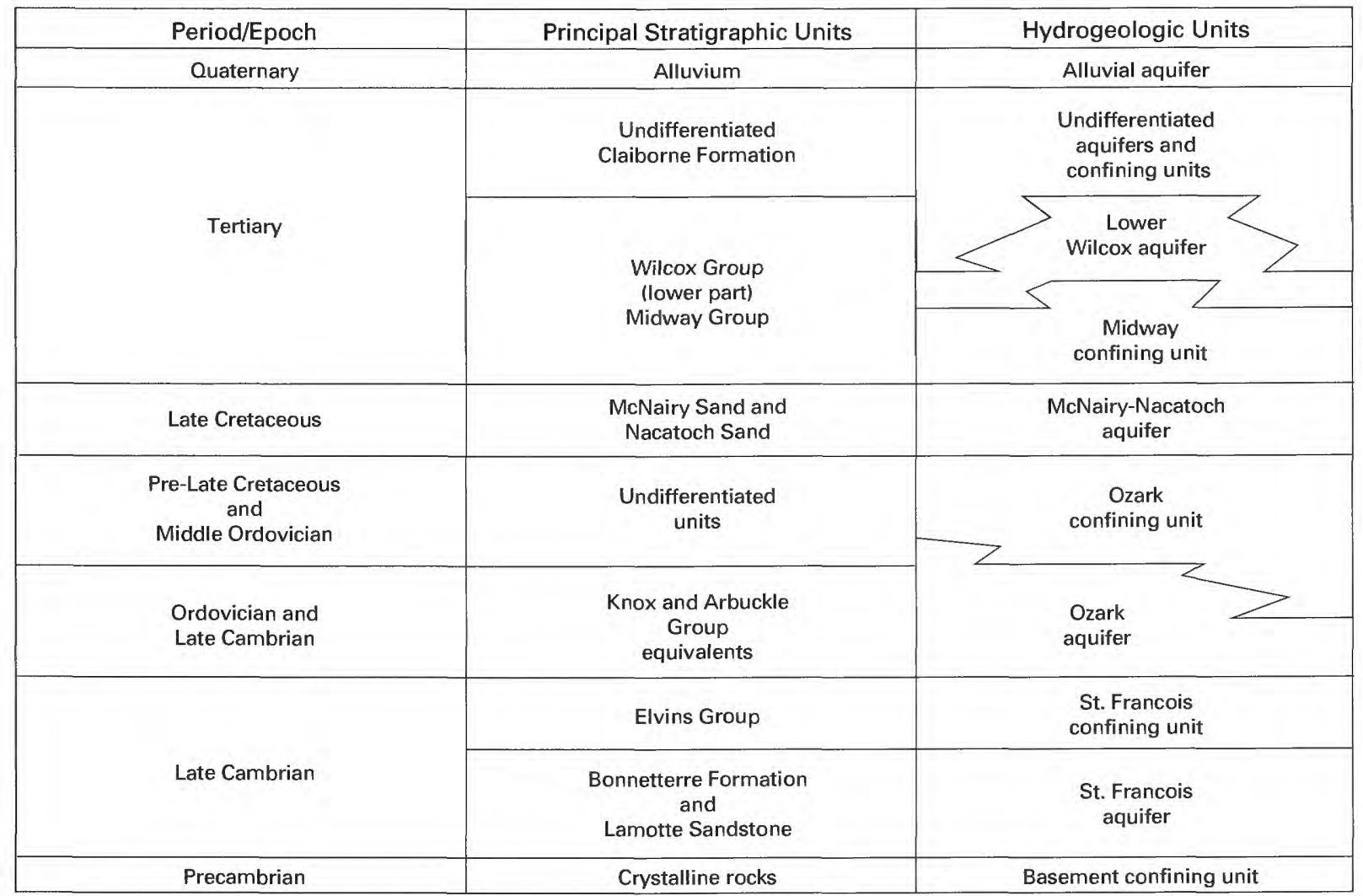

Figure 5. Columnar section of hydrogeologic units in the upper Mississippi Embayment (after J.V. Brahana, written commun., 1992).

and appendix 2). Crone and Russ (1979, p. 5) reported that, almost immediately below casing set at $2,060 \mathrm{ft}$, "artesian water from Paleozoic rocks began to flow at the rate of 4 to $6 \mathrm{gal} / \mathrm{min}$ at the surface. The flow gradually increased to about $30 \mathrm{gal} / \mathrm{min}$ as the well was deepened. At $2,303 \mathrm{ft}$, the well intersected an 8 - $\mathrm{ft}$-thick fracture zone and the artesian flow increased to more than 500 $\mathrm{gal} / \mathrm{min}$." After failing to cement the fractured zone, the well was completed at a depth of $2,316 \mathrm{ft}$. Water flowed from a string of drill pipe, the top of which was $27 \mathrm{~m}$ above ground level (Crone and Russ, 1979). This flow indicated that the excess fluid pressure at the surface was about $0.28 \mathrm{MPa}$.

The U.S. Bureau of Mines, R.B. Oliver, Jr. No. 1 well (drilled in 1945, about $35 \mathrm{~km}$ southwest of New Madrid, Mo., in the northwestern part of the rift (fig. 6)), is more significant than the New Madrid test well because of the depth from which the artesian flow originated. The artesian flow of water apparently came from fractured zones in the Boneterre Formation (Upper Cambrian) and the Elvins Group (Upper Cambrian). Grohskopf (1955, p. 79) reported that:

Between depths 2,920 and 3,000 ft, water was encountered which flowed $50 \mathrm{ft}$ above ground level at an estimated $700 \mathrm{gal} / \mathrm{min}$.***Another flow of water was encountered at $3,500 \mathrm{ft}$, and circulation was lost at several points below that depth. Several attempts were made to cement off this water but all failed, making it necessary to set a string of 4-inch standard pipe at $3,828 \mathrm{ft}$.

Another well with artesian flow of water that penetrated Paleozoic rocks was the Strake Petroleum Incorporated, T. P. Russell No. 1 well, located in Pascola, Mo. (fig. 6). Grohskopf (1955) reported that, upon completion of this well, water with a temperature of $92^{\circ} \mathrm{F}$ flowed at $150 \mathrm{gal} / \mathrm{min}$ at the surface, but no information is given about the head of flow above the ground surface. The flow, as interpreted from the log of the well in Grohskopf (1955), apparently came from Paleozoic rocks at a depth of 2,208 ft. Grohskopf (1955) also reported that water with a temperature of $110^{\circ} \mathrm{F}$ flowed at $70 \mathrm{gal} / \mathrm{min}$ from a depth of $4,405 \mathrm{ft}$ in the Benedum-Trees Oil Co., C.W. Mack No. 1 well, which is located about $11 \mathrm{~km}$ east of Blytheville, Ark. (fig. 6). These observations of artesian flow of water from deeply buried lower Paleozoic rocks are important to some arguments about the heterogeneity and magnitude of excess fluid pressure made later in this report.

Additional measurements of water levels in Paleozoic rock from wells within the embayment are few. Boswell and others (1965) reported that, although a number of flowing wells occur in the region, their discharge could not be estimated. In addition to the Oliver, Strake, and Benedum-Trees wells, Brahana and Mesko (1988, fig. 9) report 


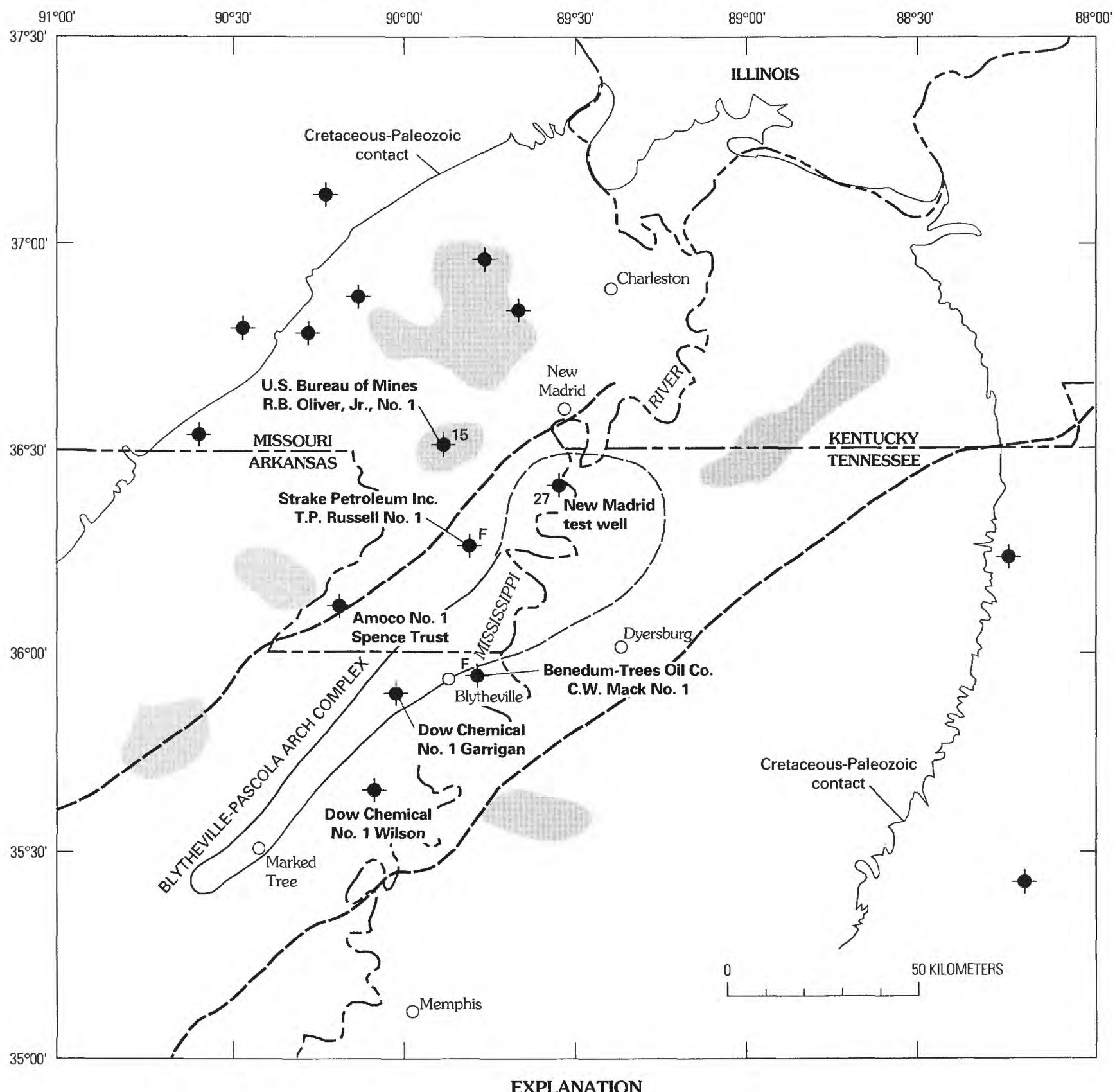

Pluton

Figure 6. Map showing locations of wells that penetrate Paleozoic rocks. Number next to well symbol is altitude, in meters, of water above ground level. Wells with "F" next to symbol were flowing, but level of water above ground level is unknown. Level of water in wells without number or letter is unknown.

measurements in eight wells drilled into Paleozoic rocks within the western part of the embayment in the "bootheel" of Missouri (fig. 6). Most of the wells are very close to the northwestern edge of the embayment (fig. 6). The altitude of the water in these wells is about the same as the altitude of the land surface, which indicates normal hydrostatic fluid pressure in the Paleozoic rocks. The lack of excess fluid pressure in these wells is probably because of the lack of a confining layer. The large flow of water from the Oliver well may be anomalous. This well is above the Malden pluton, which is estimated to be Mesozoic in age (Hildenbrand, 1985) (fig. 1). The fracture zones in the Bonneterre Formation, an aquifer, and the Elvins Group, generally a confining unit (fig. 5), may have been caused by intrusion of the pluton, which may have caused fracturing and alteration of the Paleozoic rocks into which it intruded. 


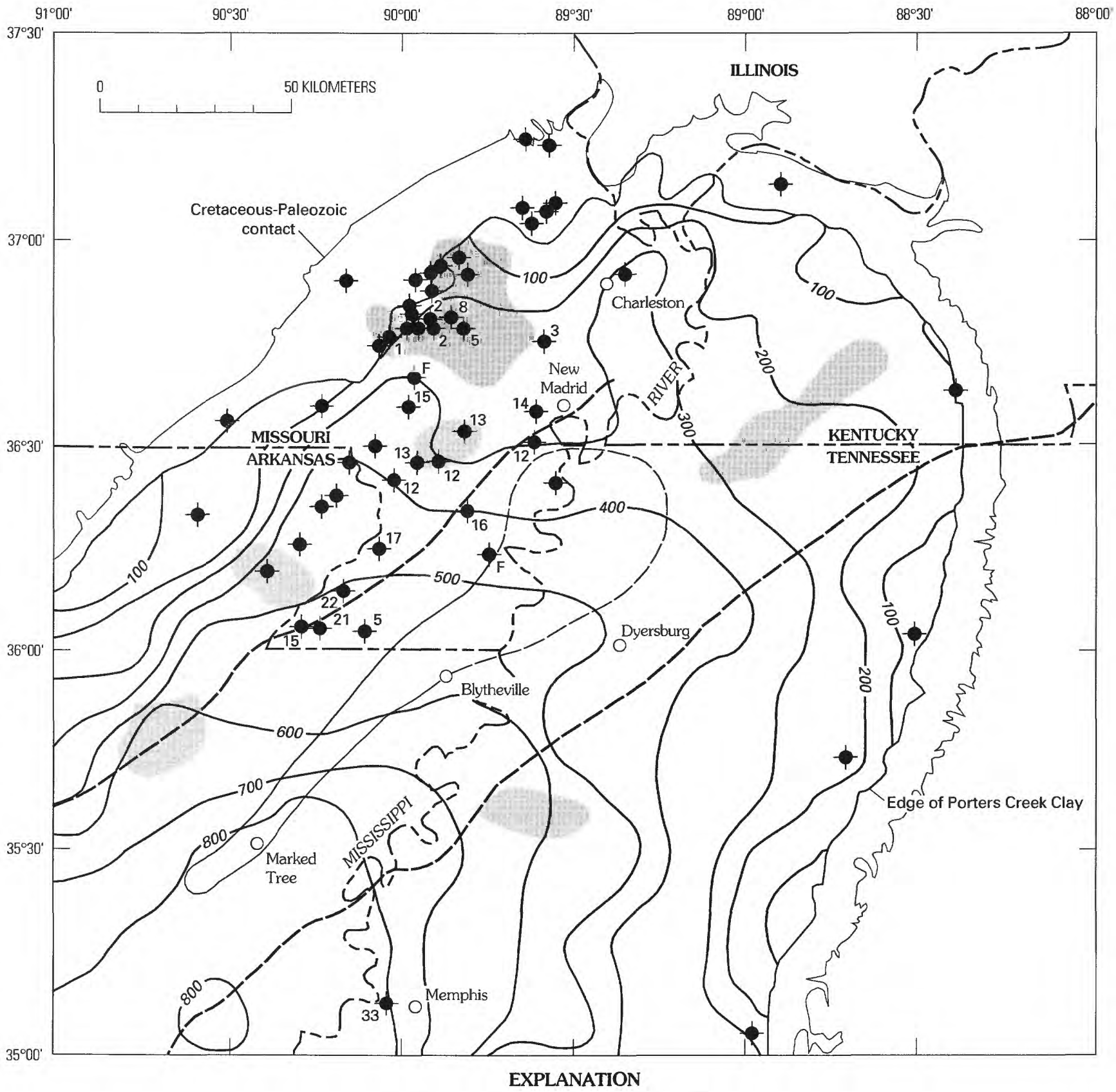

Figure 7. Map showing locations of wells that penetrate the Upper Cretaceous aquifer. Number next to well symbol is altitude, in meters, of water above ground level. Wells with "F" next to symbol were flowing, but level of water above ground level is unknown. Level of water in wells without number is below ground level. Contours indicate thickness, in feet, of Porters Creek Clay.

\section{MCNAIRY-NACATOCH AQUIFER}

Artesian heads of water from wells in the Upper Cretaceous McNairy-Nacatoch aquifer are important for municipal water supplies (Boswell and others, 1965; Luckey, 1985). Measurements of water levels in 58 wells that are north of lat $35^{\circ} \mathrm{N}$. in the embayment and that penetrate this aquifer are shown in figure 7. Twenty-eight of these measurements are from figure 10 of Brahana and Mesko (1988), and 30 are from Brahana (written commun., 1992). Water levels in many of these wells are a few meters to tens of meters above the ground surface. For example, the static water level in a well into the McNairy-Nacatoch aquifer near Memphis, Tenn., is about $33 \mathrm{~m}$ above the ground elevation (Wells, 1931). Near the eastern and western edges of the embayment, water 
levels in this aquifer are commonly below the surface altitude (fig. 7). The water levels plotted in figure 7 were measured at different times over a period of 10 years or more, and the highest levels were the earliest measurements, indicating that pumping over a long time period has reduced the levels. The water levels plotted in figure 7 are the highest recorded. A correlation of water levels with the principal zone of seismicity is somewhat speculative because of a lack of data. Where measured, water levels correlate well with the thickness of the Porters Creek Clay confining unit (fig. 7). If unmeasured pressures are also high where the Porters Creek Clay is thick, then the area of high water levels would contain the earthquake epicenters. The absence of potentiometric data for the McNairy-Nacatoch aquifer within the rift and south of the wells shown in figure 7 is because adequate water supplies are obtained less expensively from shallower aquifers (Boswell and others, 1965; Brahana and Mesko, 1988).

A comparison of the water levels and the thickness contours of the Porters Creek Clay confining unit shows an approximate positive correlation (fig. 7); that is, the water levels are highest where the thickness of the Porters Creek Clay is greatest. Water levels are below the ground surface where the confining unit is less than $200 \mathrm{ft}$ thick. In addition, Brahana and Mesko (1988) interpret the higher water levels in the Upper Cretaceous McNairy-Nacatoch aquifer near the center of the embayment to be caused by thinning of the Paleozoic-Cretaceous confining unit (fig. 5) (Brahana and Mesko, 1988) toward the center of the embayment. This thinning results in a hydraulic connection between the Paleozoic and Cretaceous aquifers and allows the pressure in the aquifers to equalize. The water levels in wells in the overlying Tertiary rocks do not indicate significantly high fluid pressure. Aquifers in these rocks, however, supply very large amounts of water for irrigation as well as for public and industrial purposes, which causes a considerable drawdown of water levels. Prior to extensive pumping, artesian flow from Tertiary rocks was probably widespread (J.V. Brahana, written commun., 1992) and may have been a factor in the extensive liquefaction of alluvium that occurred during the 1811-12 New Madrid earthquakes (Fuller, 1912).

Brahana and Mesko (1988, table 2) interpret that the McNairy-Nacatoch aquifer is recharged with fluid from Paleozoic rocks in zones above the northeastern part of the northwest boundary of the Reelfoot rift and northwestward to about the Bloomfield pluton (figs. 1 and 2). This is because high chloride content, high dissolved-solids concentrations, and trace-element constituents that are characteristic of water in the Paleozoic aquifer occur in water in the Upper Cretaceous aquifer. Also, they report Tom Kraemer's (written commun., 1986) interpretation of radium-isotope-ratio data in water from the Upper Cretaceous aquifer to indicate that the water was derived from deep Paleozoic rocks. Therefore, the chemical composition and isotope data suggest that fluid pressures at depth are high enough to cause water to flow from Paleozoic rocks into the Upper Cretaceous McNairy-Nacatoch aquifer.

Zones of hydrothermal or anomalously warm water (fig. 8) in the McNairy-Nacatoch aquifer are also inferred by Brahana and Mesko (1988) to indicate recharge from underlying Paleozoic rock. Brahana and Mesko (1988) believe that a linear zone of hydrothermal water close to the western boundary of the rift indicates upward leakage of water from Paleozoic rocks to the Upper Cretaceous aquifer through faults along the rift boundary. Luckey (1985) speculates that the high temperatures and the artesian pressure in the Upper Cretaceous aquifer may make it a possible heat source. The highest water temperatures above the normal geothermal gradients are generally between the northwestern boundary of the rift and the center of the Blytheville-Pascola arch complex. Swanberg and others $(1982$, p. 188) also reported a "well-defined thermal anomaly associated with the New Madrid seismic zone." They considered several explanations of the anomaly and ultimately favored convective heat flow from deep ground-water circulation along fractures in the upper crust as the best explanation.

\section{EVIDENCE OF ANCIENT EXCESS FLUID PRESSURE}

Detailed petrographic and scanning-electron-microscope studies of core samples of Cambrian rocks from the Reelfoot rift show rock fabrics that indicate former exces-fluid-pressure conditions. Structural fabrics that suggest fluid migration and excess fluid pressure include: (1) dilated horizontal and, subsequently, mineralized stylolites; (2) vertical and horizontal mineral-filled fractures; and (3) abundant pore space created by randomly oriented clay platelets in silty shale.

\section{STYLOLITES}

Stylolites are pressure-solution surfaces that occur as well-defined column-and-socket or sutured structures and as irregular seams lined with insoluble residues from the host rock (Park and Schot, 1968). Stylolites are commonly parallel to bedding, but they may also form at any orientation normal to the maximum principal stress direction. Stylolites are present both in arenaceous and shaly rocks in the Reelfoot rift as low-amplitude, wavy, clay-filled seams that form planes of weakness. Petrographic data show that the stylolites expanded into open fractures in the past when the hydrostatic pressure exceeded lithostatic pressure. The stylolites commonly contain layers of quartz, organic and clay residue, carbonate minerals, and minor amounts of sulfide minerals, and they are interpreted to once have been flow 


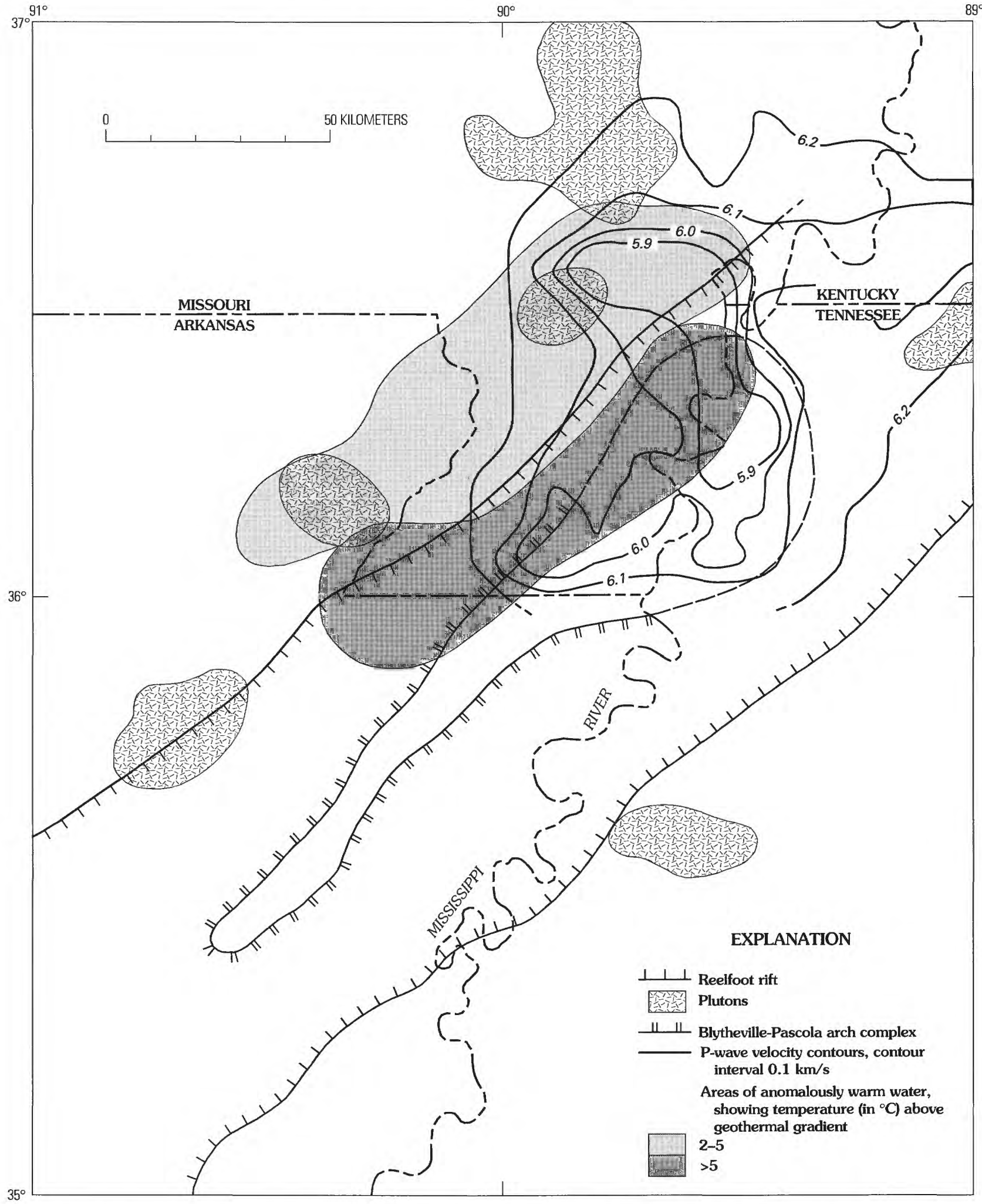

Figure 8. Map showing zones of anomalously warm water (from Brahana and Mesko, 1988) and contours of P-wave velocities (in $\mathrm{km} / \mathrm{s}$ ) in upper $14 \mathrm{~km}$ of the crust (from Al-Shukri and Mitchell, 1988) in relation to the Reelfoot rift and the Blytheville-Pascola arch complex. Solid line boundary of arch complex is from seismic reflection profiles and drill-hole data; long dashed line boundary is from drill-hole data. 


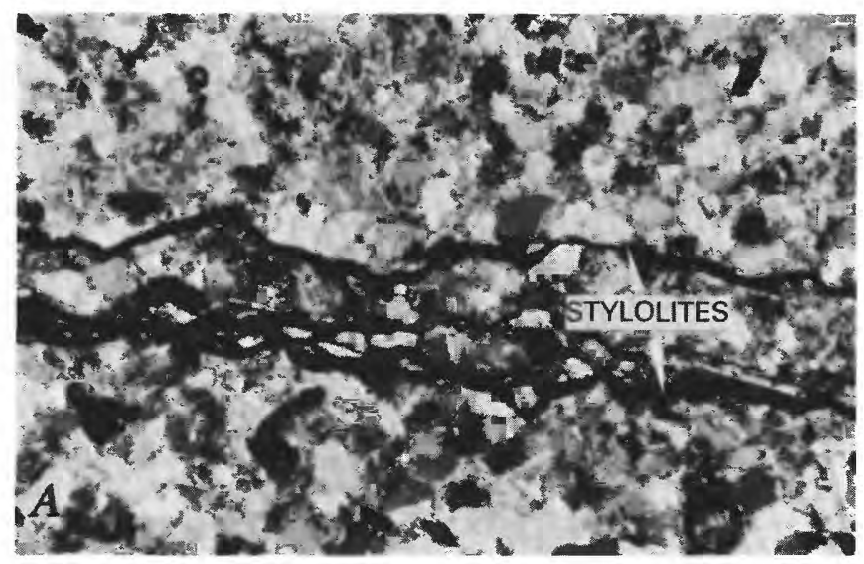

Figure 9. $A$, Thin-section photomicrograph showing stylolites in the Wilson drill hole $(12,782 \mathrm{ft})$ filled with residual clay minerals, organic residue, and minor epigenetic minerals. Horizontal field of view is approximately $2.5 \mathrm{~mm}$. $B$, Thin-section photomicrograph showing that stylolites in the Garrigan drill hole $(7,999.9 \mathrm{ft})$ have commonly undergone deformation and are filled with a succession of carbonate cements. Horizontal field of view is approximately 5 $\mathrm{mm}$.

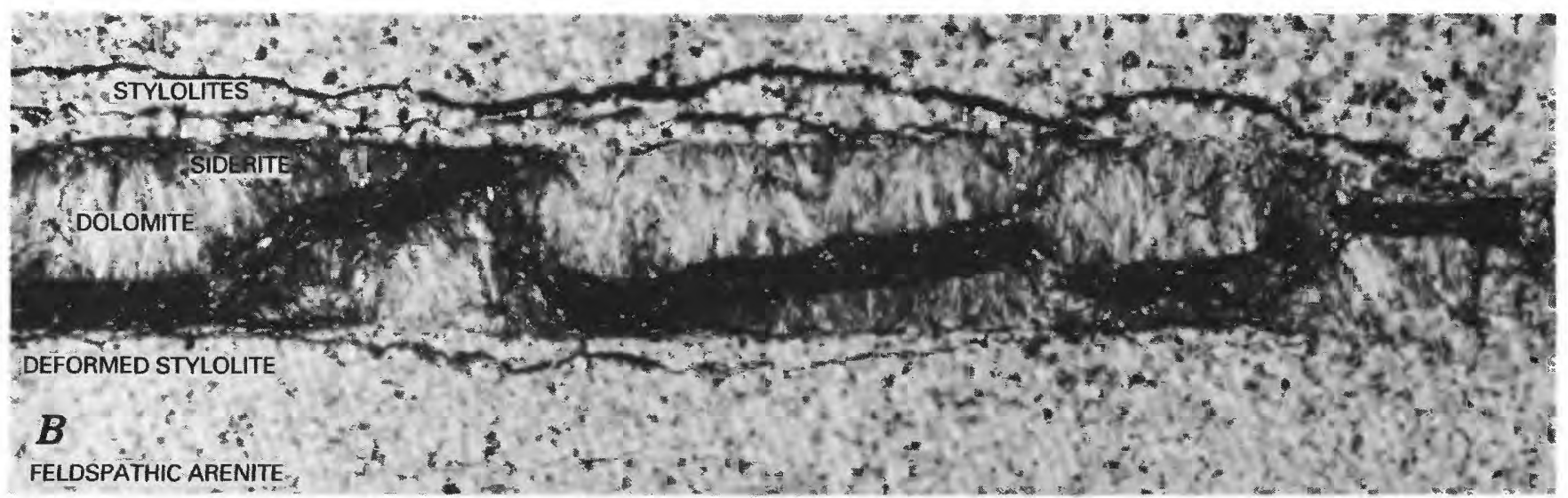

paths for solutions (Braithwaite, 1989; Bathurst, 1990; Diehl and others, 1992).

We compared deformation features in stylolites in samples of Cambrian rocks from two deep drill holes in the Reelfoot rift-the Dow Chemical No. 1 Garrigan, which is in the intensely deformed Blytheville-Pascola arch complex, and the Dow Chemical No. 1 Wilson, which is southeast of the complex (fig. 1). Stylolites in rocks from the Wilson drill hole are parallel to subparallel to bedding and are characteristically lined with insoluble organic matter and residual clay (fig. 9A); they also contain rare epigenetic monazite and pyrite that must have precipitated from hydrothermal fluids (Diehl and others, 1992). The stylolites also have slickensided clay, which is indicative of differential slip subparallel to the plane of the stylolite.

In contrast, the bedding-parallel stylolites in samples from the Garrigan drill hole commonly show evidence for multiple fluid-flow and precipitation events (fig. 9B). The residual clayey material in these samples is commonly sheared, and several generations of carbonate cement fill the dilated stylolites-siderite, dolomite, and minor ferroan dolomite. The carbonate minerals have cone-in-cone structure, which is typical of calcareous layers in overpressured shales (Stoneley, 1983) (fig. 9B). Epigenetic pyrite, sphalerite, and minor rare-earth minerals apparently accompanied carbonate mineralization in the sheared stylolites (Diehl and others, 1992) (fig. 9B). For horizontal bedding-parallel stylolites to open and allow fluid flow, pore-fluid pressure must have exceeded the lithostatic pressure of the overburden.

The stylolites in samples from the Wilson drill hole are largely in siliciclastic rocks, whereas stylolites in the Garrigan drill hole samples are in both siliciclastic rocks and shale. Swarms of microstylolites in shale from the Garrigan drill hole are both parallel and normal to bedding, which indicates a change in the maximum stress direction. The greater degree of fracturing and stylolite formation in the shale may be due to the location of the Garrigan drill hole in the severely disrupted Blytheville-Pascola arch complex or to the different physical properties and diagenetic changes between siliciclastic rocks and shale.

Carozzi and Von Bergen (1987) related enhanced porosity in connection with sutured stylolites in deeply buried carbonate rocks and the precipitation of secondary carbonate cements. But they also described low-amplitude, non-sutured stylolites in shale that had no influence on porosity development. In contrast, in our studies of rocks from the Reelfoot rift, the non-sutured stylolites in samples from deeply buried shale have been important fluid conduits in the past and have been episodically mineralized by carbonate cements (Braithwaite, 1989). The stylolites in the rift have reacted to maximum stress directions other than those that result from compaction. In responding to tensile stresses, the opened stylolites acted as lateral porous 


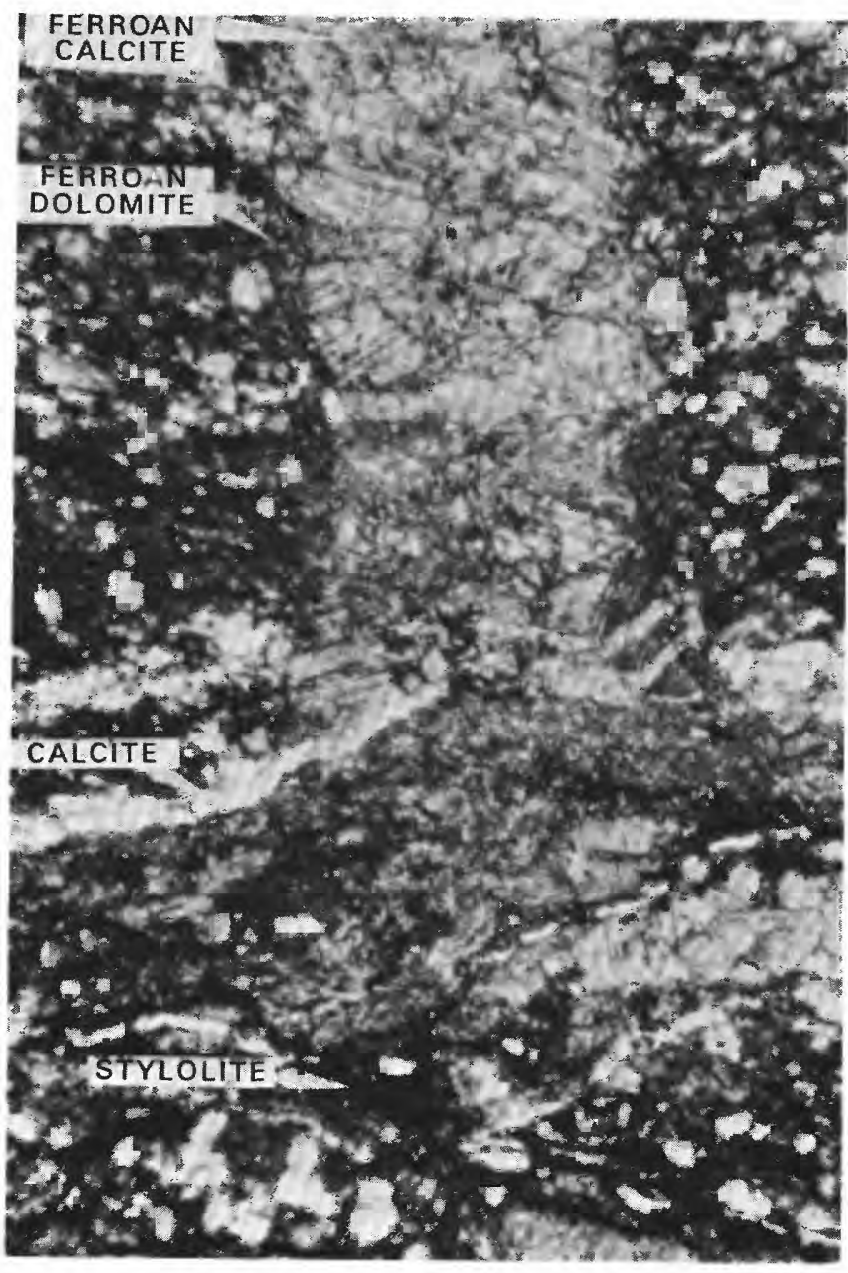

Figure 10. Thin-section photomicrograph showing a network of vertical and horizontal fractures filled with epigenetic carbonate minerals (Strake Petroleum No. 1 Russell drill hole, 4,118 ft). Vertical field of view is approximately $2.5 \mathrm{~mm}$.

pathways through the rock. Diagenetic cements filling the stylolites are precipitated from fluids that may have migrated in response to seismic events, not from local sources due to dissolution of minerals along the stylolite (Sibson and others, 1975).

\section{MINERAL-FILLED FRACTURES}

A network of mineral-filled vertical and horizontal fractures with planar surfaces is present at mesoscopic and microscopic scales in core and cuttings from the Garrigan, Wilson, and Strake drill holes in the Reelfoot rift (fig. 6) (Swolfs, 1992). This network of fractures suggests vertical and horizontal continuity of permeability at the time of their formation. Swolfs (1992) interprets the vertical fractures in brittle sandstone to have formed as a result of extension that was caused by excess fluid pressure. Micro-thrust faults and veinlets with incremental fillings of quartz and carbonate minerals indicate multiple episodes of dilation, possibly due to excess fluid pressures (fig. $9 B$ ). Mineral fillings in the horizontal fractures, like the mineral fillings in stylolites, almost certainly indicate excess fluid pressure. In the Garrigan drill hole, a set of vertical veinlets, normal to bedding and limited to the siliciclastic rocks, commonly terminates against horizontal, clay-lined stylolites where strain energy was relieved along the ductile surface. Another, older, set of vertical fractures extends over a vertical distance of $3,000 \mathrm{ft}$ through both the siliciclastic rocks and shale (Swolfs, 1992). These fractures may have provided flow paths for fluids (Diehl and others, 1992). The Strake, Garrigan, and Wilson drill holes are approximately $80 \mathrm{~km}$ apart and all have fractures in Paleozoic rocks filled with the same sequence of ferroan dolomite followed by ferroan calcite cements (fig. 10). Assuming these carbonate minerals precipitated from a common source of fluids during late Paleozoic time, this same paragenetic sequence suggests regional hydraulic continuity and widespread excess fluid pressures. To summarize the above, opening of the fractures is required to allow deposition of minerals, and this opening suggests that fluid pressure in the rocks had to be greater than the lithostatic load.

Although the vertical fractures in the Wilson and Garrigan drill holes have the same sequence of mineralization (siderite, dolomite, ferroan dolomite, and ferroan calcite), these minerals are not present in stylolites in the Wilson drill hole. Only stylolites in the Garrigan drill hole and the horizontal fractures in the Strake drill hole, both of which are in the Blytheville-Pascola arch complex, have a similar sequence of authigenic carbonate mineralization. Samples from the Wilson drill hole, which is outside of the Blytheville-Pascola arch complex, contain minor dolomite-filled, horizontal fractures and do not show evidence of repeated opening of these fractures or of the stylolites. This suggests that rocks southeast of the arch complex had lower fluid pressure than the rocks within the arch complex during the period of fracturing.

\section{SHALE FABRIC}

Scanning-electron-microscope studies of samples from the thick sequence of Cambrian-age shale in the Garrigan drill hole show fabrics that indicate excess fluid pressure. Layers of randomly oriented illitic clay platelets, in which porosity is high, are interlayered with well-oriented clay platelets, in which porosity is low (figs. $11 A$ and $11 B$ ). These clay-mineral fabrics are characteristic of overpressured and normal shale, respectively, in the Gulf Coast region ( $\mathrm{O}^{\prime} \mathrm{Brien}$ and Slatt, 1990) where high-porosity shale layers have greater fluid pressure than low-porosity layers.

The high silt content of the shale in the rift is also a factor that contributes to excess-fluid-pressure conditions. The silt grains mixed with clay in the shale suggest that the rate of deposition and burial of the shale was rapid. During deposition, clay platelets tend to settle in random orientation 

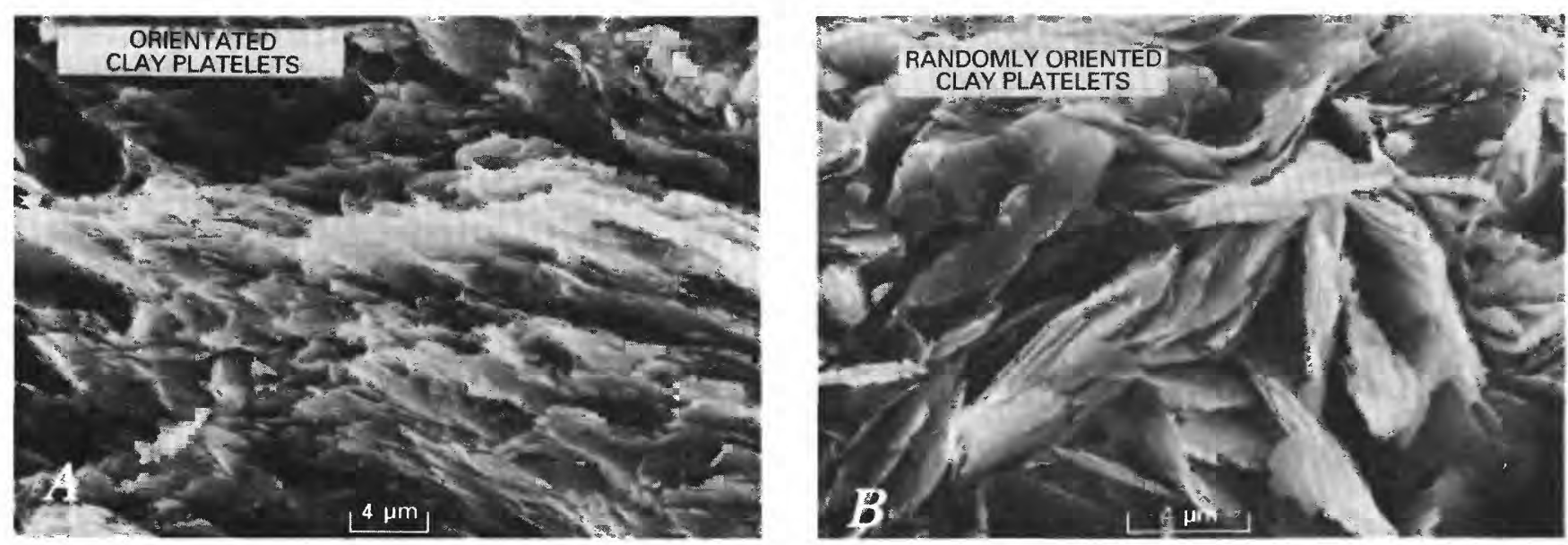

Figure 11. A, Scanning-electron photomicrograph showing well-laminated clay platelets parallel to bedding of shale (Dow Chemical No. 1 Garrigan drill hole, 8,002 ft). B, Scanning-electron photomicrograph showing randomly oriented clay platelets in shale (Dow Chemical No. 1 Garrigan drill hole, $11,420 \mathrm{ft}$ ).

around a quartz grain, creating pore space that traps fluids. Energy-dispersive $\mathrm{X}$-ray analyses indicate that the clay in the shale is mostly illite with some chlorite. Throughout the Paleozoic and with deep burial, diagenetic reactions may have added interstitial water to the shale by converting smectite to illite (Hower and others, 1976). Adding interstitial water to pore spaces by this process would elevate the fluid pressure, especially if the water could not migrate rapidly through overlying confining layers.

All of these factors-unoriented clay fabric, porous silty-shale layers, and the possible release of water through diagenetic conversion of clay-may have been factors that could contribute to the development of excess fluid pressure.

\section{CAUSES AND ESTIMATES OF EXCESS FLUID PRESSURES}

The evidence cited above leave little doubt that some stratigraphic units and fault zones in the upper Mississippi Embayment are currently under excess fluid pressure and that parts of the stratigraphic section during late Paleozoic and possibly early Mesozoic time had excess fluid pressure. The causes of excess fluid pressure have been studied extensively because of its importance to drilling for oil and gas and because of its importance in understanding the process of hydrocarbon migration and accumulation (Dutta and Levin, 1987). Some of the most commonly cited reasons for excess fluid pressure include: (1) mechanical-compaction disequilibrium, (2) fractures formed by tectonic extension or compression (i.e., extension would increase the volume of a mass of rock and decrease the pressure; compression would decrease the volume of rock and increase the pressure), (3) diagenetic phase changes of minerals, (4) tectonism, (5) aquathermal pressuring, (6) organic metamorphism, and (7) gravity fluid flow (Dutta and Levin, 1987, chapters 1 and 2). Modeling studies show that compaction-driven fluid flow is too slow to maintain the temperatures of the ore-bearing fluids at the point at which ore was deposited in the discharge area of the Mississippi Valley-type deposits in the Ozarks (Cathles and Smith, 1983; Bethke, 1986). Fluid flow caused by changes in rock volume is analogous to compaction, and, presumably, the flow would also be slow. No evidence of large-scale diagenetic phase changes, aquathermal pressuring, or organic metamorphism is currently known. Of the several causes of excess fluid pressure listed above, gravity flow appears to be the most likely cause of current excess fluid pressure in the upper Mississippi Embayment. Our concept of current gravity flow is shown in the post-Late Cretaceous panel of figure 2 . The one requirement in common for excess fluid pressure to exist over geologic time is that fluid flow must be retarded or restricted. No rock, however, is totally impervious, and some fluid will always flow away from an excessively pressured zone.

We infer that paleo-topography is the primary cause of ancient excess fluid pressures, although compaction or mineral diagenesis may also have been contributing factors at times. Both mechanisms require that relatively impermeable rock units be present to restrict flow. Compression may be a factor for excess pressure today, particularly with the presence of confining layers.

Our concept of the cause and direction of ancient fluid flow is shown in the Pennsylvanian and Permian panel of figure 2. In addition to favorable topographic conditions for gravity fluid flow, the structural setting of the Reelfoot rift and the Mississippi Embayment syncline, both of which are structural lows, enhance excess-fluid-pressure conditions because aquifers and confining units increase in depth toward the lows, thereby increasing the potential hydraulic head. 


\section{CAUSE OF CONTEMPORARY EXCESS FLUID PRESSURE}

As shown in figure 7, the highest fluid pressures in the upper Mississippi Embayment correlate closely with the thickness of the Midway Group confining unit (Porters Creek Clay), which overlies the McNairy-Nacatoch aquifer. Also, as stated above, this aquifer is in hydraulic continuity with aquifers in the underlying Paleozoic rocks. The flow paths of fluids from recharge areas for these aquifers cannot be explicitly defined, but recharge into the highly fractured rocks and through sinkholes in the Ozarks is well documented (Harvey, 1980).

The flow paths are controlled by fracture systems. Fractures occur within the hydrogeologic units and contribute to their permeability. Fractures in fault zones, however, transect the hydrogeologic units and provide permeable zones through which fluids can flow vertically or horizontally from one hydrogeologic unit to another. Also note that no rock is a perfect confining unit and some leakage of fluid occurs through all rocks.

Locally, much of the recharged water resurfaces at large springs, but a large volume of the water must be driven by gravity toward the topographic and structural low in the embayment. This flow is self-evident from the artesian flow of water from wells into Paleozoic and Cretaceous rocks within the embayment and from the chemical composition and temperature of the water in the wells. Permeability in the Paleozoic rocks is largely a function of the extent and abundance of fractures, both of which may be highly variable. Thus, the permeability is probably very heterogeneous. The evidence of this heterogeneous permeability of the Paleozoic rocks in the Ozarks is shown by the distribution of many very large springs and by tracing the flow paths of water that feeds the springs (Harvey and others, 1983; Harvey, 1980).

The Elvins Group, which is generally a confining unit, is overlain by the Potosi Dolomite (Upper Cambrian), which is one of the best aquifers in the Cambrian section (Harvey, 1980). If the axial part of the rift was not disrupted by the Blytheville-Pascola arch complex, a permissible interpretation is that excess fluid pressure due to topographic relief of the Potosi Dolomite would not extend below the Elvins Group. However, as indicated in figures 3 and 4, the entire section of Paleozoic rocks is warped up against the Blytheville-Pascola arch complex. Formation of this complex resulted in intense fracturing and faulting as shown by seismic reflection and refraction profiles (Hamilton and McKeown, 1988; Hamilton and Mooney, 1990). Fluids in Paleozoic rocks, such as the Potosi Dolomite, are probably in hydraulic continuity with rocks in the arch. The Paleozoic aquifers are permeable because of fractures or sedimentary fabric, and these rocks are warped up against the complex. Fluids in the Paleozoic rocks probably enter fault and fracture zones in the arch complex, and the fluid pressure would be transmitted vertically through confining units in rocks adjacent to the complex. Several wells provide evidence that this does occur. The fluid from the New Madrid test well flowed from a fault zone in part of the Elvins Group (Crone, 1981), and water flowed from several zones in the Bonneterre Formation and Elvins Group in the Oliver and Benedum Trees wells. This strongly indicates fluid flow in the lower part of the Paleozoic section of rocks. Heterogeneous permeability is also evident in petrographic studies of samples of the Elvins Group in the Garrigan drill hole (Diehl and others, 1992; Swolfs, 1992). As described in the section Evidence of Ancient Excess Fluid Pressure, some parts of the drill core and cuttings show pores formed by randomly oriented clay platelets and other parts show clay platelets compressed with little evidence of porosity. Although heterogeneous permeability to depths of several kilometers is indicated by several kinds of data, magnetotelluric data indicate that rocks to depths of greater than $3 \mathrm{~km}$ in the arch complex have much lower resistivity than adjacent rock (Stanley and Rodriquez, 1992). This implies that, although the magnetotelluric method does not resolve zones of lower resistivity in detail, the rocks in the arch as a whole contain more saline fluid and are under higher fluid pressure than the rocks adjacent to the arch complex.

\section{CAUSE OF ANCIENT EXCESS FLUID PRESSURE}

The geologic history of the New Madrid region shows that topographic and structural conditions similar to those of today probably existed at the end of the Paleozoic Era. As stated in the previous section, the requirements for long-lasting excess fluid pressure are gravity flow of fluid into aquifers sealed by confining strata. Although fractured carbonate rocks and minor interbeds of sandstone would have been aquifers throughout most of Paleozoic time, widespread confining units were not deposited until the Mississippian and Pennsylvanian (fig. 2). The Ozark and Nashville domes, which have been structurally high since Cambrian time, were exposed during most of the Pennsylvanian (McKee and Crosby, 1975, plates 15A and 15B). Many of the sinkholes and caves, which are exposed today in the Ozarks, started to form before Pennsylvanian time (Wanless, 1975). Prior to or concomitant with the formation of the Blytheville-Pascola arch complex, a hydrologic regime with fluids driven by gravity flow very probably existed during the Pennsylvanian. The petrographic studies we described earlier show that excess fluid pressure existed not only in the most deeply buried rocks in the middle of the rift but also in rocks on the shelf adjacent to the rift. Post-Pennsylvanian uplift of the region caused erosion of the confining strata and destroyed the stratigraphic conditions needed to maintain excess fluid pressure.

A reversal of fluid-flow directions apparently occurred during Late Pennsylvanian or Early Permian time. This 
reversal is inferred from multidisciplinary studies of the lead-zinc ore deposits in the Ozarks. Most geologists who have studied these ores concluded that they were deposited from hot brine solutions migrating through deep basins (Leach and Rowan, 1986). Identification of the basin(s) from which the brines originated and the fluid driving force, however, is controversial (Ohle, 1980). Leach and Rowan (1986) proposed that the source of the fluids was the Arkoma Basin and that gravity flow from the topographically high Ouachita Mountains south of the basin forced fluids out of the basin and up to the Ozark dome. Diehl and others (1992) and Goldhaber (oral commun., 1991) propose that the Reelfoot rift was possibly a flow path and that the topographically high Appalachian Mountains east of the rift forced gravity flow of fluids northwestward out of deeply buried sedimentary rocks in the rift and into the Ozark dome. Gregg and Shelton (1989) interpret the distribution of trace elements as evidence of multiple-basin flow paths for lead-zinc mineralization. They inferred that ore fluid came from basins both north and south of the lead-zinc deposits in the Ozarks. We agree with the suggestion of multiple basins and flow paths and also with the suggestion of Bethke (1986) and Glick (written commun., 1988) that the Pascola arch area was high enough to cause gravity flow away from the arch. Bethke (1986) proposed flow northward, toward the Illinois Basin, and Glick (written commun., 1988) proposed that flow was westward, toward the Ozarks, during latest Paleozoic time and possibly throughout the Jurassic. Our arguments are similar to Glick's, but we base our broader interpretations on additional data. Seismic reflection profiles (figs. 3 and 4) and drill-hole data show that nearly all Paleozoic rocks above the arch complex have been eroded. A pre-Upper Cretaceous unconformity truncates the arch of faulted Paleozoic strata. Stearns and Marcher (1962) estimated 8,000 ft to $15,000 \mathrm{ft}$ of rock were eroded off the crest of the arch. Because the Ozark dome has always remained a structural and topographic high, it was never covered by as thick a section of rocks as those deposited in the Reelfoot rift. The thickness of Cambrian rocks on the dome compared to the thickness of Cambrian rocks in drill holes in the rift provides insight into the amount of rock eroded from the arch complex. Cambrian rocks on the north flank of the Ozark dome are about 1,200 $\mathrm{ft}$ thick (Howe and Koenig, 1961). The thickness of Cambrian rocks in the Wilson drill hole is about 5,600 ft (E.E. Glick, written commun., 1989), and the same stratigraphic interval in the Garrigan drill hole is about 7,400 ft thick (Collins and others, 1992). These data show that this section of Cambrian rocks alone is at least $6,200 \mathrm{ft}$ thicker in the middle of the rift than on the Ozark dome. Adding the remainder of the Paleozoic section to this thickness would yield a total thickness of rocks along the axial zone of the Reelfoot rift prior to formation of the arch complex quite compatible with the estimate of $8,000 \mathrm{ft}$ to $15,000 \mathrm{ft}$ made by Stearns and Marcher (1962). The removal of such a great thickness of rocks in the arch compared to the thickness of equivalent rocks on the dome during the same time suggests that uplift of the arch complex must have been much greater than the uplift of the Ozark dome during the same time.

Based on stratigraphic data, the time of uplift is inferred to be between Late Pennsylvanian and Late Cretaceous (E.E. Glick, written commun., 1988). Several sets of independent data consistently indicate this approximate time of uplift. Paleomagnetic data show that the ore deposits in the Ozarks formed during Late Pennsylvanian and Early Permian (Wu and Beales, 1981; Wisniowiecki and others, 1983). Petrographic and fluid-inclusion studies of samples from the Bonneterre Formation in the Amoco Spence Trust No. 1 drill hole (fig. 6) show three episodes of burial and uplift in the Reelfoot rift (Tobin, 1991). Tobin (1991) concludes that the last uplift after deepest burial of sediments occurred in Late Mississippian to Early Pennsylvanian time and that, after subsidence during the Cretaceous and Tertiary, uplift has been occurring and continuing to the present. If the ores in the Ozarks were deposited from brines, some of which may have originated or passed though the arch complex, then reversal of fluid flow (from the flow direction that existed prior to formation of the arch complex) must have occurred during the same time interval. This uplift and erosional history strongly indicates that the arch complex started forming during the Pennsylvanian when the rift was filled with the greatest thickness of sedimentary rocks and when the constrained fluid was under the greatest pressure.

The above geologic history of the Ozark and upper Mississippi Embayment region provides an explanation of why and where excess fluid pressure conditions existed at the end of the Paleozoic Era, and it provides an explanation of the forced opening of stylolites, which were filled with mineralizing fluids. The regional structural, topographic, and lithologic conditions at the end of the Paleozoic Era were similar to those of today, except that the location of topographically high areas were shifted, and, therefore, the direction of fluid flow was reversed.

\section{IMPLICATIONS OF EXCESS FLUID PRESSURE ON EARTHQUAKES IN THE NEW MADRID SEISMIC ZONE}

\section{The apparent spatial correlation of earthquakes in the} New Madrid seismic zone with excess fluid pressure observed in artesian wells (fig. 12) and inferred from low $P$-wave seismic velocities and magnetotelluric data seems more than fortuitous and implies a causal relation between the earthquakes and the excess fluid pressure as well as with the structural high. Al-Shukri and Mitchell (1988) noted a general correlation of lower $\mathrm{P}$-wave velocities with seismicity, which is apparent by comparing the seismicity of figure 1 with the P-wave velocity contours on figure 8 . Al-Shukri and Mitchell (1988) attribute the lower velocities to high pore pressure. They supported their arguments for the 
lower velocities due to high pore pressure with the laboratory data of Nur and Simmons (1969), who showed that P-wave velocities are 15-20 percent less in water-saturated samples that have pore pressure equal to external pressure. Al-Shukri and Mitchell (1988) also noted that the greatest reduction in velocity is in the upper $5 \mathrm{~km}$ of sedimentary rocks, where water is probably of meteoric origin. The data and arguments in this report conform to their interpretations.

Quantitative arguments supporting a causal relationship cannot be made because the failure criterion and state of stress of rocks in the hypocentral zone of the earthquakes are not known. However, estimates of excess fluid pressure at the surface and at depths from which artesian water flowed from Paleozoic rocks can be made and may provide insight into whether earthquakes could be expected to occur as the result of excess fluid pressure.

Assuming the pressure gradient for the commonly briny water from wells in Paleozoic rocks is $0.01 \mathrm{MPa} / \mathrm{m}$, the excess hydrostatic pressure from the $27-\mathrm{m}$ head of water estimated at the New Madrid test well is about $0.27 \mathrm{MPa}$ and is a minimum value because water was flowing from the drill pipe. This low excess pressure is unlikely to trigger earthquakes based on the results of a detailed study of the amount of pore pressure required to initiate earthquakes (Raleigh and others, 1972). By determining the state of stress, the coefficient of friction, and by monitoring changes in pore pressure in the Rangely oil field, Raleigh and others (1972) found that earthquakes could be initiated or stopped by pore pressure changes of 3.5 MPa. However, in a study of a northeastern Ohio earthquake that occurred in 1986, $12 \mathrm{~km}$ from wells into which hazardous waste was being injected under high pressure, Nicholson and others (1988) estimated that the fluid injection into the wells did not raise the pore pressure in the hypocentral zone of the earthquake more than 0.4 $\mathrm{MPa}$, which does not agree with the Rangely data. They recognized, however, that some earthquakes have been caused by changes in pore pressure of only a few bars and concluded that their data were inadequate to determine the minimum amount of pore pressure increase necessary to cause the 1986 earthquake.

Several factors common to the Rangely and Ohio areas are: (1) the pore pressure at the depths of the earthquakes were on the order of 20-25 MPa, (2) focal mechanisms of earthquakes in both areas showed strike-slip movements, and (3) both areas are in parts of the continental interior considered to be tectonically stable. These attributes are similar to those in the New Madrid seismic zone, and, thus, the results of these studies might be applicable to the New Madrid zone.

Based on the above studies, an obvious conclusion is that the small excess fluid pressure of $0.27 \mathrm{MPa}$ estimated at the surface of the New Madrid test well would not be likely to trigger earthquakes. The multiple correlations of direct and circumstantial evidence of excess fluid pressure with the earthquakes in the New Madrid seismic zone, however, seem to be more than a fortuitous relationship and require some explanation. Several possibilities are obvious. One is that only a small change (a few bars) in the pore pressure of rocks that are close to failure may be needed to trigger earthquakes. Historic and instrumental records of abundant and ongoing seismicity (Nuttli, 1973; Stauder and others, 1976) in the New Madrid seismic zone seems to indicate that rocks in the seismic zone are and have been near failure for at least several decades. A second possibility is that the pore pressure at hypocentral depths is much greater than the pressures indicated by hydrostatic head measured at the surface in artesian wells. Both of these possibilities are supported by circumstantial and documented evidence. A third possibility is that the failure criterion and state of stress are quite different at hypocentral depths than assumed from conventional methods of estimating them. This possibility cannot be evaluated within the scope of this report.

The evidence that increases in pore pressure as small as $0.01 \mathrm{MPa}$ can trigger earthquakes is documented by studies of reservoir-induced seismicity (Simpson, 1986) and by the correlation of seismicity with changes in river stages. Some investigators suggest that increases in pore pressure as small as $0.03 \mathrm{MPa}$, which are related to changes in water levels of rivers, can trigger earthquakes in regions where rocks are close to failure (Costain and others, 1987). The explanation of the process by which small changes of water levels near the surface can propagate to the hypocentral depths of earthquakes is controversial, but the relation of increases and decreases in seismicity with changes in water levels appears to be sound.

Several arguments can be made that pore pressure may exceed hydrostatic pressure in some lithologic or fracture zones at hypocentral depths in the New Madrid seismic zone. We cite the opening of stylolites as evidence of ancient excess fluid pressure, and we argue that the fluid movement was primarily gravity driven, but compaction or diagenetic phase changes may have contributed to hydraulic gradients. Also, we cite differences in the porosity of Upper Cambrian shale and the distribution of fractures as evidence of heterogeneous permeability. These conditions apparently existed during the late Paleozoic and possibly the early Mesozoic. The opening of stylolites, described in earlier sections, required that the hydrostatic fluid pressure be at least equal to the lithostatic pressure. Because structural, lithologic, and topographic conditions today are similar to those during the late Paleozoic, the inference may be made that zones of higher porosity and permeability with fluid overpressure exist today in the lower part of the Paleozoic section, as in the past. Evidence of this is from the excess pressure of water from the lower parts of the Paleozoic section penetrated in the New Madrid test, the Strake, the Oliver, and the Benedum-Trees wells. Although excess-fluid-pressured zones cannot be identified explicitly within the New Madrid seismic zone, the abundant evidence of excess fluid pressure from hydrologic, stratigraphic, petrographic, geophysical, 
Table 1. Estimates of excess fluid pressures at bottom of drill pipes.

[See fig. 6 for complete names and locations of drill holes. Altitude 1, altitude (in m) of recharge area; altitude 2, altitude (in $\mathrm{m}$ ) of top of drill pipe; estimated excess pressure 1 , estimated excess pressure (in $\mathrm{MPa}$ ) from difference in altitude and pressure gradient of $0.01 \mathrm{MPa} / \mathrm{m}$; excess pressure 2, excess pressure (in $\mathrm{MPa}$ ) equivalent to frictional loss in drill pipe]

\begin{tabular}{cccccc}
\hline $\begin{array}{c}\text { Well } \\
\text { name }\end{array}$ & $\begin{array}{c}\text { Flow } \\
(\mathrm{L} / \mathrm{min})\end{array}$ & Altitude 1 & Altitude 2 $\begin{array}{c}\text { Estimated } \\
\text { excess } \\
\text { pressure 1 }\end{array}$ & $\begin{array}{c}\text { Excess } \\
\text { pressure 2 }\end{array}$ \\
\hline New Madrid & & & & & \\
test well ....... & $1,892.5$ & 305 & 114 & 1.9 & 1.1 \\
Oliver ............ $2,649.5$ & 305 & 98 & 2.1 & 3.1 \\
Strake............. 567.8 & 305 & 82 & 2.2 & 0.1 \\
Benedum & & & & & \\
Trees............. 265.0 & 305 & 82 & 2.2 & 0.4 \\
\hline
\end{tabular}

and seismological data suggests that excess-fluid-pressure zones may be very common, if not abundant, particularly in parts of the Reelfoot rift that are highly faulted.

Excess hydrostatic pressure may be considerably higher at the depth at which water enters a drill pipe than the pressure estimated at the top of the pipe. It is obvious that for flow to occur up the pipe, the pressure at the bottom of the pipe must be greater than at the top. Two methods of estimating the pressure at the bottom of a drill pipe are: (1) assume static conditions for water level in the pipe (that is, no flow): the pressure at the bottom of the pipe is the difference in altitude between the recharge area and the altitude at the top of the pipe multiplied by the pressure gradient of the water $(0.01 \mathrm{MPa} / \mathrm{m}),(2)$ calculate frictional loss of pressure in the pipe from the depth at which water enters the pipe to the top of the pipe where water is discharging. Some of the available data needed to apply these methods have considerable uncertainties. For example, estimating the altitude of the recharge areas is a subjective judgment that is based on the concept that the pressure at any depth cannot exceed the highest altitude that water is entering a hydrologic system, even though much of the water may be discharged through springs or leakage through confining layers in transit to the greatest depth at which the water is tapped. On the basis of structure contours of the tops of the Ozark and St. Francois aquifers (Imes, 1990a, 1990b), the altitude of the highest recharge areas for both aquifers is about $305 \mathrm{~m}$. Computation of frictional losses in a pipe is based mainly upon empirical data and a standard method of calculating frictional losses given by Rouse $(1950$, p. 112). This method involves computing the Reynolds number from which a frictional coefficient is estimated and used in the Weisbach equation that relates frictional loss of pressure in a pipe as a function of velocity of flow, the diameter of the pipe, and the length of the pipe. Probably the most important parameter in these calculations is the uncertainties in estimates or measurements of flow out of the top of a drill pipe because loss of pressure through a pipe is a function of the velocity of flow squared. Given these caveats, table 1 shows the estimated excess fluid pressures using each method for the depths at which water entered drill pipes of four wells that penetrated Paleozoic rocks and lists the parameters used to make the estimates.

Pressures at the bottom of a well, calculated by the two methods given above, should be equal values. The frictional loss of pressure for all wells, except the Oliver well, is less than the pressure estimate from the difference in altitude of the recharge area to the bottom of the well. This difference may be the result of loss of pressure through the aquifers. The excessive pressure computed from frictional loss in the drill pipe of the Oliver well is $1 \mathrm{MPa}$ more than the pressure estimated from differences in altitude. We cannot explain this difference except as noted above that the rate of flow is a critical parameter in the frictional-loss equation. Flow from the New Madrid test well was measured through a weir (A.J. Crone, oral commun., 1992) and is probably a good estimate. We suspect that rates of flow for the other three wells were only estimated and could have large errors.

More important than the pressure estimates at the bottom of the drill holes in Paleozoic rocks is the pressure at the source of the water entering the drill holes. Analogous to the reasoning for computing frictional loss of pressure in the drill pipe, the pressure at the source must be greater than that at the bottom of the pipe in order for water to rise to the bottom of the pipe. Frictional loss of pressure would occur for water flowing up through rocks from the source to the bottom of a drill pipe. Data are inadequate, however, to estimate this loss in pressure. The minimum pressure that might be expected is the pressure estimated at the bottom of the drill pipe plus the calculated hydrostatic pressure to the source.

If a causal relationship between contemporary earthquakes and changes in fluid pressure exists as we suggest, contemporary earthquakes may be representative of long-lived background seismicity and are not aftershocks of the 1811-12 sequence of earthquakes because the current fluid-pressure conditions have probably existed in the Blytheville-Pascola arch complex since at least Eocene time (after deposition of the Porters Creek Clay). The evidence that excess fluid pressure existed in the lower part of the Porters Creek Clay is the presence of sandstone dikes in the Porters Creek at several places in western Kentucky (Glenn, 1906; Olive, 1980). The suggestion that the current background of seismicity has existed since the Eocene is contradicted, however, by the fact that, during the Tertiary, the state of stress was probably very different than it is today. Northeast-striking normal faults are common in Tertiary rocks, and some displace the Lafayette Gravel (Grohskopf, 1955; Olive, 1980; McKeown, 1982), whose age is considered to be Pliocene or Pleistocene. McKeown and others (1988) summarize the evidence and arguments for these ages. Northeast-trending normal faults indicate that the max- 
imum principal horizontal stress would have been oriented northeast-southwest, which is about $35^{\circ}$ from its present orientation. If, therefore, seismicity started when the state of stress changed to its present orientation, the current rate of seismicity may have been occurring since the Pliocene ( 5 $\mathrm{Ma})$ or Pleistocene (1.6 Ma). This inference is somewhat surprising because of the lack of evidence of more than three (Russ, 1979) (or possibly only one (Wesnousky and Leffler, 1992)) large-magnitude earthquakes in the New Madrid seismic zone during the Quaternary. If the recurrence rate of large earthquakes is about 600 years, as estimated by Russ (1979), then more than 10,000 large earthquakes would be expected to occur during about the last million years. However, there is no evidence for this large number of earthquakes. A major assumption in postulating the large number of earthquakes is that the level of stress today, as well as the orientation, has been the same during the past million years or so.

It is possible that the recurrence of earthquakes within excess-fluid-pressure zones may be a function of the rate of flow of fluids from one zone to another or of the time required to recharge a fault zone to excess fluid pressure after failure of the zone. Recharge of a fault zone large enough to cause large earthquakes may take thousands of years, depending upon the rate of fluid flow and the rate of leakage from a zone. The changes in porosity and permeability of fault zones caused by fracturing from a large earthquake must also be considered; past pressures could have been higher or lower than contemporary pressures. Fluctuations in excess fluid pressure over hundreds or thousands of years certainly may be expected as the result of changes in rainfall or changes in the access of water to aquifers as the result of erosion and incision of streams into carbonate rocks in the Ozarks. In addition, even though leakage through confining layers may occur, subsurface flow of water under a high hydrostatic head will occur. Dissolution and deposition of minerals will be a continuous, although slow, process that will ultimately change the porosity and permeability of the rocks through which water flows. Because artesian flow of water from deeply buried Paleozoic rocks is occurring today, dissolution and deposition of minerals must be considered active contemporary processes. Qualitative estimates of these processes and their rates could be made based upon mineralogic and geochemical studies related to ore deposits, but those estimates are beyond the scope of this report.

If our conclusion is correct that earthquakes may occur where faults are under excess fluid pressure in a major zone of structural deformation such as the Blytheville-Pascola arch complex, similar pressure and structural conditions elsewhere should be considered as potential earthquake source zones. Hamilton and Mooney (1990) suggested that the $8-\mathrm{km}$-wide fault zone that is the southeastern boundary of the Reelfoot rift has low seismic-velocity characteristics, similar to those of the arch complex. These authors also noted that minor earthquake activity occurs in this zone.
Excess fluid pressure in the Cretaceous aquifer near Memphis, Tenn. (Wells, 1931), and presumably in underlying Paleozoic rocks, implies that the zone may have the same hydrologic characteristics as the arch complex. The concordance among these data suggests that the fault zone bounding the southeastern margin of the Reelfoot rift may be a source zone with a potential for earthquakes nearly as great as that of the arch complex. Available seismic reflection data, however, do not show unambiguously that faults in the southeastern rift boundary zone extend to depths as great as those that bound the Blytheville-Pascola arch complex. Earthquakes on faults in the southeast boundary zone presumably would have smaller source dimensions than faults in the arch complex. Rupture of faults in the southeast boundary fault zone of the Reelfoot rift, therefore, may not produce earthquakes as large as those that may occur in or along the boundaries of the Blytheville-Pascola arch complex. Much more data are required to resolve this question.

\section{CONCLUSIONS}

The principal conclusions made from the data and arguments presented in this report are summarized as follows:

1. Hydrologic data provide direct evidence of excess fluid pressure at depths of about $1.3 \mathrm{~km}$, and this pressure is the result of gravity-driven flow. These data also show that pressure is maintained by confining units, which severely retard vertical flow from underlying aquifers. The principal confining unit is the Porters Creek Clay in the Midway Group of Paleocene age.

2. The geologic history of the upper Mississippi Embayment and adjacent highlands and the petrographic evidence of ancient excess fluid pressure indicates that the regional geologic and hydrologic regime that is causing excess pressure today may be special. The late Paleozoic and possibly early Mesozoic appear to be the only other times when a similar regime existed. Because of the similarity of regimes and evidence of contemporary deep subsurface flow of fluids, it is reasonable to assume that high fluid pressure, and dissolution and precipitation of minerals at hypocentral depths, may be occurring today. These processes, of course, would continually change porosity and permeability of the rocks through which fluids flowed. The rate of change of these parameters, however, is beyond the scope of this report.

3. Drill-hole data provide direct evidence of fluid flow from fault zones. Interpretation of seismic reflection profiles indicate that the Blytheville-Pascola arch complex has many faults that extend through the Paleozoic section; these faults are inferred to provide zones of vertical continuity for 


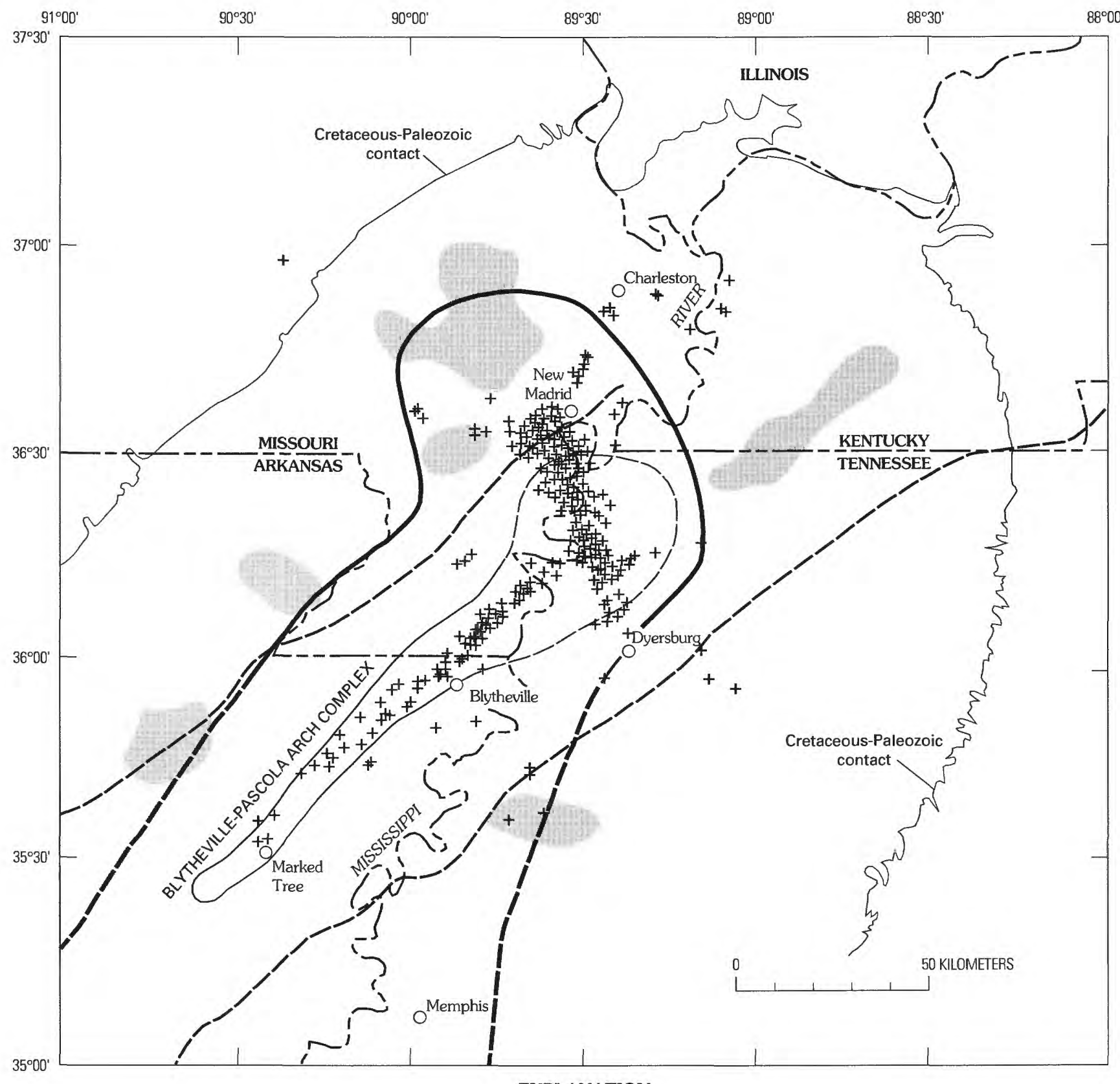

EXPLANATION

- Rift boundary + Earthquake epicenter

Pluton

Figure 12. Generalized map derived from figures 1,6, and 7 showing relationship of the Blytheville-Pascola arch complex and excessfluid-pressure zone to seismicity. Excess-fluid-pressure zone is within the heavy line, dashed where uncertain.

the flow of fluid and thus allow pressure to be distributed heterogeneously. The chemical characteristics and thermal data of water from wells in Paleozoic rocks and the contiguous Cretaceous aquifer indicate upward flow of water from depths of several kilometers.

4. The spatial correlation of earthquakes with the Blytheville-Pascola arch complex and the distribution of excess fluid pressure within the Reelfoot rift (fig. 12) appears to be more than fortuitous. Estimates of excess fluid pressures at shallow hypocentral depths, however, are less than those required to trigger earthquakes according to conventional ideas on the state of stress in the Earth's crust. Yet, the correlation between changes in seismicity that result from very small changes in pore pressure related to filling of reservoirs and river stages suggest that current ideas on the state of 
stress may need to be modified.

5. If earthquakes in the New Madrid seismic zone are causally related to zones of excess fluid pressure in the Blytheville-Pascola arch complex, then many important ramifications should be considered. These include providing a physical basis for delimiting seismic zones, determining the duration of background seismicity, and possibly estimating recurrence rates of earthquakes in source zones as a function of size of the zone and time required to pressurize it by fluid flow.

\section{REFERENCES CITED}

Al-Shukri, H.J., and Mitchell, B.J., 1988, Reduced seismic velocities in the source zone of New Madrid earthquakes: Bulletin of the Seismological Society of America, v. 78, p. 1491-1509.

Andrews, M.C., Mooney, W.D., and Mayer, B.J., 1985, The relocation of microearthquakes in the northern Mississippi Embayment: Journal of Geophysical Research, v. 90, p. 10223-10236.

Bathurst, R.G.C., 1990, Thoughts on the growth of stratiform stylolites in buried limestones, in Heling, D., Rothe, P., Forstner, U., and Stoffers, P., eds., Sediments and Environmental Geochemistry: Berlin, Springer-Verlag, p. 3-15.

Bethke, C.M., 1986, A numerical model of compaction-driven groundwater flow and heat transfer and its application to the paleohydrology of intracratonic sedimentary basins: Journal of Geophysical Research, v. 90, no. B8, p. 6817-6821.

Boswell, E.H., Moore, G.K., MacCary, L.M., and others, 1965, Cretaceous aquifers in the Mississippi Embayment: U.S. Geological Survey Professional Paper 448-C, 37 p.

Brahana, J.V., and Mesko, T.O., 1988, Hydrogeology and preliminary assessment of regional flow in the Upper Cretaceous and adjacent aquifers in the northern Mississippi Embayment: U.S. Geological Survey Water Resources Investigations Report $87-4000,65 \mathrm{p}$.

Braithwaite, C.J.R., 1989, Stylolites as open fluid conduits: Marine and Petroleum Geology, v. 6, p. 93-96.

Buschbach, T.C. and Atherton, E., 1979, History of the structural uplift of the southern margin of the Illinois Basin, in Palmer, J.E. and Dutcher, R.R., eds., Depositional and Structural History of the Pennsylvanian System of the Illinois Basin: Part 2: invited papers, field trip. Ninth International Congress of Carboniferous Stratigraphy and Geology, p. 112-115.

Carozzi, A.V., and Von Bergen, D., 1987, Stylolites, porosity in carbonates-A critical factor for deep hydrocarbon production: Journal of Petroleum Geology, v. 10. no. 3, p. 267-282.

Cathles, L.M., and Smith, A.T., 1983, Thermal constraints on the formation of Mississippi Valley-type lead-zinc deposits and their implications for episodic basin dewatering and deposit genesis: Economic Geology, v. 78, p. 983-1002.

Collins, D.S., Taylor, M.E., Repetski. J.E., and Palmer, A.R., 1992, New sedimentologic and paleontologic data for the Dow Chemical \#1 B.L. Garrigan drill hole, Mississippi County. Arkansas: U.S. Geological Survey Open-File Report 92-6, 38 p.
Costain, J.K., Bollinger, G.A., and Speer, J.A., 1987, Hydroseismicity-A hypothesis for the role of water in the generation of intraplate seismicity: Seismological Research Letters, v. 58, no. 3, p. 41-64.

Crone, A.J., 1981, Sample description and stratigraphic correlation of the New Madrid test well-1-X, New Madrid County, Missouri: U.S. Geological Survey Open-File Report 81-426, 25 p.

Crone, A.F., McKeown, F.A., Harding, S.T., Hamilton, R.M., Russ, D.P., and Zoback, M.D., 1985, Structure of the New Madrid seismic source zone in southeastern Missouri and northeastern Arkansas: Geology, v. 13, p. 547-550.

Crone, A.J., and Russ, D.P., 1979, Preliminary report on an exploratory drill hole-New Madrid test well-1-X in southeast Missouri: U.S. Geological Survey Open-File Report 79-1216, $12 \mathrm{p}$.

Diehl, S.F., Goldhaber, M.B., Taylor, C.D., Swolfs, H.C., and Gent, C.A., 1992, Microstructures in the Cambrian Bonneterre Formation, Lamotte Sandstone, and basal clastic rocks of southeast Missouri and northeast Arkansas-Implications of regional sulfide occurrence in stylolites and extensional veinlets for ore genesis, in Thorman, C.H., ed., Application of Structural Geology to Mineral and Energy Resources of the Central and Western United States: U.S. Geological Survey Bulletin 2012, Chapter A, p. A1-A13.

Dutta, N.C., and Levin, F.K., 1987, Geopressure: Geophysics Reprint Series No. 7, Society of Exploration Geophysicists, 365 p.

Ervin, P.C., and McGinnis, L.D., 1975, Reelfoot rift-Reactivated precursor to the Mississippi Embayment: Geological Society of America Bulletin, v. 86, p. 1287-1295.

Fuller, M.L., 1912, The New Madrid earthquake: U.S. Geological Survey Bulletin 494, $119 \mathrm{p}$.

Glenn, L.C., 1906, Underground waters of Tennessee and Kentucky west of Tennessee River and of an adjunct area in Illinois: U. S. Geological Survey Water-Supply Paper 164, pl. 1 and fig. 7.

Gregg, J.M., and Shelton, K.L., 1989, Minor and trace-element distributions in the Bonneterre Dolomite (Cambrian), southeast Missouri-Evidence for possible multiple-basin fluid sources and pathways during lead-zinc mineralization: Geological Society of America Bulletin, v. 101, p. 221-230.

Grohskopf, J.G., 1955, Subsurface geology of the Mississippi Embayment of southeastern Missouri: Missouri Geological Survey and Water Resources, v. 37. ser. 2, 133 p.

Hamilton, R.M., and McKeown, F.A., 1988, Structure of the Blytheville arch in the New Madrid seismic zone: Seismological Research Letters, v. 59, no. 4, p. 117-121.

Hamilton, R.M., and Mooney, W.D., 1990, Seismic-wave attenuation associated with crustal faults in the New Madrid seismic zone: Science, v. 248, p. 351-354.

Harvey, E.J., 1980, Ground water in the Springfield-Salem Plateaus of southern Missouri and northern Arkansas: U.S. Geological Survey Water-Resources Investigations 80-101, $66 \mathrm{p}$.

Harvey, E.J., Skelton, J., and Miller, D.E., 1983, Hydrology of carbonate terrane-Niangua, Osage Fork, and Grandglaize Basins, Missouri: U.S. Geological Survey Water-Resources Report No. 35, p. 1-118. 
Hildenbrand, T.G., 1985, Rift structure of the northern Mississippi Embayment from the analysis of gravity and magnetic data: Journal of Geophysical Research, v. 90, p. 607-612.

Hildenbrand, T.G., Rosenbaum, J.G., and Reynolds, R.L., 1992, High-resolution aeromagnetic study of the New Madrid seismic zone-A preliminary report: Seismological Research Letters, v. 63 , no. 3 , p. $209-221$.

Howe, J.R., and Thompson, T.L., 1984, Tectonics, sedimentation, and hydrocarbon potential of the Reelfoot rift: Oil and Gas Journal, November 12, p. 179-190.

Howe, W.B. (compiler), and Koenig, J.W, (ed.), 1961, The stratigraphic succession in Missouri: Missouri Geological Survey and Water Resources, v. 40, 2nd series, 85 p.

Hower, J., Eslinger, E.V., Hower, M.E., and Perry, E.A., 1976, Mechanisms of burial metamorphism of argillaceous sediment; 1. Mineralogical and chemical evidence: Geological Society of America Bulletin, v. 87, p. 725-737.

Imes, J.L., 1990a, Major geohydrologic units in and adjacent to the Ozark plateaus province, Missouri, Arkansas, Kansas, and Oklahoma-Ozark aquifer: U.S. Geological Survey Hydrologic Investigations Atlas, HA-711E.

$1990 \mathrm{~b}$, Major geohydrologic units in and adjacent to the Ozark plateaus province, Missouri, Arkansas, Kansas, and Oklahoma-St. Francois aquifer: U.S. Geological Survey Hydrologic Investigations Atlas, HA-711C.

Imes, J.L., and Smith, B.J., 1990, Areal extent, stratigraphic relation, and geohydrologic properties of regional geohydrologic units in southern Missouri: U.S. Geological Survey Hydrologic Investigations Atlas, HA-711I.

Kane, M.F., Hildenbrand, T.G., and Hendricks, J.D., 1981, A model for the tectonic evolution of the Mississippi Embayment and its contemporary seismicity: Geology, v. 9, p. 563-567.

Leach, D.L., and Rowan, E.L., 1986, Genetic link between Ouachita fold belt tectonism and the Mississippi Valley-type lead-zinc deposits of the Ozarks: Geology, v. 14, p. 931-935.

Luckey, R.R., 1985, Water resources of the Southeast Lowlands, Missouri, with a section on Water Quality, by D.L. Fuller: U.S. Geological Survey Open-File Report 84-4277, 134 p.

Maxey, G.B., 1964, Hydrostratigraphic units: Journal of Hydrology. v. 2, p. 122-129.

McKee, E., and Crosby, E., 1975, Paleotectonic investigations of the Pennsylvanian System in the United States: U.S. Geological Survey Professional Paper 853, 349 p.

McKeown, F.A., 1982, Overview and discussion, in McKeown, F.A., and Pakiser, L.C., eds., Investigation of the New Madrid, Missouri, Earthquake Region: U.S. Geological Survey Professional Paper 1236-H, p. 1-14.

McKeown, F.A., Jones-Cecil, M., Askew, B.L., and McGrath, M.B., 1988, Analysis of stream-profile data and inferred tectonic activity, eastern Ozark mountains region: U.S. Geological Survey Bulletin 1807, 39 p.

McKeown, F.A., Hamilton, R.M., Diehl, S.F., and Glick, E.E., 1990, Diapiric origin of the Blytheville and Pascola arches in the Reelfoot rift, East-Central United States-Relation to New Madrid seismicity: Geology, v. 18, p. 1158-1162.

Mooney, W.D., Andrews, M.C., Ginzburg, A., Peters, D.A, and Hamilton, R.M., 1983, Crustal structure of the northern Mississippi Embayment and a comparison with other continental rift zones: Tectonophysics, v. 94, p. 327-348.
Nicholson, C., Roeloffs, E., and Wesson, R.L, 1988, The northeastern Ohio earthquake of 31 January 1986: Bulletin of the Seismological Society of America, v. 78, no. 1, p. 188-217.

Nur, A., and Simmons, G., 1969, The effect of saturation on velocity of low porosity rocks: Earth and Planetary Science Letters, v. 71, p. 183-193.

Nuttli, O.W., 1973, The Mississippi valley earthquakes of 1811 and 1812-Intensities, ground motion, and magnitudes: Bulletin of the Seismological Society of America, v. 63, p. 227-248.

O'Brien, N.R., and Slatt, R.M., 1990, Argillaceous Rock Atlas: Springer-Verlag, $141 \mathrm{p}$.

Ohle, E.L., 1980, Some considerations in determining the origin of ore deposits of the Mississippi Valley-type; Part II: Economic Geology, v. 75, p. 161-172.

Olive, W.W., 1980, Geologic maps of the Jackson Purchase region, Kentucky: U.S. Geological Survey Miscellaneous Investigations Series Map I-1217, scale 1:250,000.

Park, W.C., and Schot, E.H., 1968, Stylolites-Their nature and origin: Journal of Sedimentary Petrology, v. 38, no. 1, p. 175-191.

Raleigh, C.B., Healy, J.H., and Bredehoeft, J.D., 1972, Faulting and crustal stress at Rangely, Colorado, in Heard, H.C., Borg, N.L., and Raleigh, C.B., eds., Flow and Fracture of Rocks: Geophysical Monograph Series, v. 16, p. 275-284.

Rouse, Hunter, 1950, Engineering Hydraulics: New York, John Wiley and Sons, Inc.

Russ, D.P., 1979, Late Holocene faulting and earthquake recurrence in the Reelfoot Lake area, northwestern Tennessee: Geological Society of America Bulletin, pt. 1, v. 90, p. 1013-1018.

Schwalb, H.R. 1982, Paleozoic geology of the New Madrid area: U.S. Nuclear Regulatory Commission, NUREG/CR-2909, $61 \mathrm{p}$.

Seaber, P.R., 1988, Hydrostratigraphic units, in Back, W., Rosensheir, J.S., and Seaber, P.R., eds., Hydrogeology: Boulder, Colorado, Geological Society of America, The Geology of North America, v. 0-2, p. 9-14.

Sibson, R.H., 1990, Rupture nucleation on unfavorably oriented faults: Bulletin of the Seismological Society of America, v. 80, no. 6, p. 1580-1604.

Sibson, R.A., Moore, J. McM., and Rankin, A.H., 1975, Seismic pumping-A hydrothermal fluid transport mechanism: Journal of the Geological Society of London, v. 131, p. 653-659.

Simpson, D.W., 1986, Triggered earthquakes: Annual Review Earth Planetary Sciences, v. 14, p. 21-42.

Stanley, W.D., and Rodriguez, B.D., 1992, Structure of the Reelfoot rift as interpreted from 2-D magnetotelluric models: Seismological Research Letters, v. 63, no. 3, p. 223-232.

Stauder, William, Kramer, M., Fischer, G., Schaefer, Stephen, and Morissey, S.T., 1976, Seismic characteristics of southeast Missouri as indicated by a regional telemetered microearthquake array: Bulletin of the Seismological Society of America, v. 66, no. 6, p. 1953-1964.

Stearns, R.G., 1957, Cretaceous, Paleocene, and lower Eocene geologic history of the northern Mississippi Embayment: Geological Society of America Bulletin, v. 68, p 1077-1100.

Stearns, R.G., and Marcher, M.V., 1962, Late Cretaceous and subsequent structural development of the northern Mississippi Embayment area; Geological Society of America Bulletin, v. 73, p. 1387-1394. 
Stoneley, R., 1983, Calcite veins, overpressures, and primary oil migration: American Association of Petroleum Geology Bulletin v. 67, p. 1427-1428.

Swanberg, C.A., Mitchell, B.J., Lohse, R.L., and Blackwell, D.D., 1982, in McKeown, F.A., and Pakiser, L.C., eds., Investigations of the New Madrid, Missouri, Earthquake Region: U.S. Geological Survey Professional Paper 1236-M, p. 185-189.

Swolfs, H.S., 1992, Structural features in the Dow Chemical B.L. Garrigan well, Mississippi Co., Arkansas, and their paleotectonic implications: Seismological Research Letters, v. 63, no. 3, p. 243-248.

Tobin, R.C., 1991, Diagenesis, thermal maturation and burial history of the Upper Cambrian Bonneterre Dolomite, southeastern Missouri-An interpretation of thermal history from petrographic and fluid inclusion evidence: Organic Geochemistry, v. 17, no. 2, p. 141-151.

Wanless, H.R., 1975, Missouri and Iowa, in McKee, E.D., and Crosby, E.J., eds., 1975, Paleotectonic Investigations of the
Pennsylvanian System in the United States: U.S. Geological Survey Professional Paper 853, Part I, Chapter F, p. 97-114.

Wells, F.G. 1931, A preliminary report on the water supply of Memphis, Tennessee; U.S. Geological Survey Water-Supply Paper 638, p. 1-34.

Wesnousky, S.G., and Leffler, Lisa, 1992, On the search for paleoliquefaction in the New Madrid seismic zone: Seismological Research Letters, v. 63, no. 3, p. 343-348.

Wisniowiecki, M.J., Van der Voo, Rob, McCabe, Chad, and Kelly, W.C., 1983, A Pennsylvanian pole from the mineralized Late Cambrian Bonneterre Formation, southeast Missouri: Journal of Geophysical Research, v. 88, no. B8, p. 6540-6548.

Wu, Y., and Beales, F., 1981, A reconnaissance study by paleomagnetic methods of the age of mineralization along the Viburnum trend, southeast Missouri: Economic Geology, v. 76, p. 1879-1894.

Zoback, M.D., and Zoback, M.L., 1981, State of stress and intraplate earthquakes in the United States: Science, v. 213, p. 96-104.

Published in the Central Region, Denver, Colorado

Manuscript approved for publication September 28, 1993

Edited by Richard W. Scott, Jr.

Graphics prepared by Wayne Hawkins

Photocomposition by Norma J. Maes 